\title{
17. MIT GUYOT: DEPOSITIONAL HISTORY OF THE CARBONATE PLATFORM FROM DOWNHOLE LOGS AT SITE 878 (LAGOON) ${ }^{1}$
}

\author{
James G. $\mathrm{Ogg}^{2}$
}

\begin{abstract}
The Aptian-Albian platform succession at Site 878 has two distinct phases, separated by a 200-m-thick blanket of volcanic and limestone breccia. The lower Aptian succession has an initial onlap of shallow-water algal-microbial-rich facies followed by a series of lagoonal to shallow-water facies. This platform was terminated in the middle to late Aptian by debris from two major volcanic eruptions.

The upper carbonate platform was established in the late Aptian. A thick interval of lagoonal deposits shallowed in the ?early Albian into an emergent island of storm-deposited rudstone, overlain by a series of upward-shallowing facies successions or parasequences. The middle to late Albian platform is characterized by three to four major cycles of deepening to lagoonal conditions followed by a shallowing trend into accumulations of storm-reworked bioclastics or shallow-water algal-microbial-rich facies. Exposure surfaces may terminate the cycle before the next deepening episode. The biostratigraphy of this succession is inadequate to allow correlation to established eustatic sea level cycles.

The deepening event that led to the permanent drowning of the carbonate platform appears to have begun like the other cycles of deepening and shoaling. However, the guyot platform did not undergo another shoaling phase, and the uppermost $27 \mathrm{~m}$ of platform sediments preserved in Hole 878 A are typical "lagoonal" deposits of gastropod-rich wackestone with sporadic storm beds.
\end{abstract}

\section{OVERVIEW}

"Massachusetts Institute of Technology" (MIT) Guyot $\left(27.3^{\circ} \mathrm{N}\right.$, $151.9^{\circ} \mathrm{E}$ ) is an isolated feature close to the Wake Seamount Group (see site map preceding title page). Site 878 is in the middle of a 730-m-thick Aptian-Albian platform that developed in two pulses with an intervening volcanic episode. Reversed polarity of the underlying volcanic edifice indicates a Barremian or older age. The lower, 120 -m-thick carbonate unit of early Aptian age begins with highenergy shoals of skeletal and oolitic grainstone followed by fluctuating restricted to open-marine lagoonal conditions, with at least one episode of pelagic influence. The platform was abruptly terminated during the late early Aptian when a volcanic eruption blasted through the atoll, pulverizing the platform at the vent area, and deposited 200 $\mathrm{m}$ of breccia composed of volcanic and limestone clasts. A second carbonate platform resumed by late Aptian to Albian in a sand shoal to lagoonal setting, resulting in $400 \mathrm{~m}$ of peloid grainstone and overlying gastropod-rich wackestone with at least one incursion of pelagic influence. The oldest pelagic limestone contained in the overlying manganese nodules is latest Albian, which constrains the age of drowning. The irregular topography of the drowned surface of the MIT Guyot platform, coupled with the leaching and iron staining of the uppermost limestones, suggest that a period of emergence could have preceded the drowning of the platform.

Integration of logging data and cored lithologies enable a detailed analysis of this general facies development (Fig. 1, back pocket). Logs of different physical parameters, such as resistivity, density, and natural gamma-ray intensity, supplemented by Formation MicroScanner (FMS) imagery, indicate a complex stratigraphy of varying grain sizes and cementation. These physical properties and lithologic data have been merged into a meter-by-meter physical lithology column with associated interpretations of depositional environments and identification of possible sea-level trends. Four to five main depositional cycles of transgressive deepening through progradational shallowing could be identified in the carbonate platform succession.

\footnotetext{
${ }^{1}$ Haggerty, J.A., Premoli Silva, I., Rack, F., and McNutt, M.K. (Eds.), 1995. Proc. $O D P$, Sci. Results, 144: College Station, TX (Ocean Drilling Program).

Department of Earth and Atmospheric Sciences, Purdue University, West Lafayette. IN 47907, U.S.A.
}

\section{INTRODUCTION AND PROCEDURE FOR FACIES ANALYSIS}

A full suite of geophysical, geochemical and FMS tools was run from the bottom of the suspended drill pipe at 17.2 meters below seafloor (mbsf) to the upper portion of the volcanic basalt flow facies at 737 mbsf. A second FMS run was made within the lower igneous complex from approximately 807 to $885 \mathrm{mbsf}$. Because of deteriorating hole conditions within the volcanic flow sequence, the upper igneous complex from 737 to 807 mbsf was not logged. Because of the placement of different tools on the strings, the total depth penetration by each tool varies within these logging intervals.

Core recovery within the $400 \mathrm{~m}$ of platform carbonates in Hole $878 \mathrm{~A}$ averaged only $2 \%$, and within the lower $140 \mathrm{~m}$ averaged only $6 \%$. Therefore, these logs are invaluable for interpreting the facies succession and sea-level fluctuations within the carbonate platform. In particular, the high-resolution microresistivity borehole-wall imagery from the FMS tool is excellent for determining the thickness and vertical succession of lithologies displaying similar "resistivity textures," which, in turn, can be interpreted as specific carbonate facies.

The procedure for interpreting the depositional history of Site 878 from the combination of core recovery and downhole logs consists of the following steps.

1. Depths of logging runs are calibrated to each other and related to coring depths. The FMS logs are graphically displayed in various formats and scales for visual interpretation of resistivity features. The geochemical logs are processed to obtain realistic relative fluctuations of each element.

2. Distinct carbonate facies recovered in cores are compared with the logging data to obtain a characteristic logging "signature" for each type. This allows recognition of these facies types in intervals where core recovery was sparse. This "ground-truth" calibration was especially important for the FMS resistivity imagery.

3. A composite description of logging features and associated core recovery is made of the hole, which incorporates preliminary interpretation of the vertical succession of facies. The array of highresolution logging data enabled suites of lithologic subunits to be defined and parasequence trends to be distinguished. 
4. The facies succession is interpreted in terms of shifting depositional environments and relative sea-level fluctuations. At each level of this chain of interpretations, various assumptions and models need to be incorporated; I will make an effort to clarify most of these steps.

\section{CALIBRATION AND PROCESSING OF KEY LOGS}

\section{Depth Shifting}

Logging data are initially collected relative to the meters of logging wire suspended below the drill-rig floor and adjusted for the spacing of tools on the particular tool string. However, this initial array of data generally does not correspond to the cored intervals within the hole as measured by the lowered pipe during drilling operations. There are several factors that contribute to this mismatch, and a series of calibrations must be made, first to the position of the drill pipe, then between the different logs. Because of the very poor recovery throughout Hole $878 \mathrm{~A}$ and the inability to uniquely assign any of the few pieces of lithology to the detailed borehole logging, I have used the compensated logging depths of the FMS tools as the standard for all descriptions and depths of features. Therefore, it is important to summarize how these depths were derived.

The drill pipe during the logging runs is at a known depth below the dual-elevator stool on the rig floor (in turn, $15.3 \mathrm{~m}$ above mean sea level during the Site 879 drilling), and all cores were drilled with respect to this same reference. The initial contact of the drill string with the seafloor ("bottom felt depth") is then used to convert drilling depths to "meters below seafloor" (mbsf). This "bottom felt depth" was 1337.6 "meters below rig floor" (mbrf) for Hole 879A, implying that the seafloor was 1323.0 "meters below sea level" (mbsl). Therefore, the drill depths of cores (mbrf) were converted into depth within Hole $879 \mathrm{~A}$ (mbsf) by subtracting $1337.6 \mathrm{~m}$ (Shipboard Scientific Party, 1993).

The different logging runs have varying degrees of stretch of the wireline. Therefore, a natural gamma-ray tool (NGT) is a part of each logging tool string, and distinctive natural gamma peaks within the rock succession are used to depth-shift each log with respect to a standard run. The different logging records were later interactively depth shifted by the Lamont-Doherty Earth Observatory Borehole Research Group (Lamont-BRG) with reference to the NGT record from the geochemical run (ACT/GST/NGT), and to the seafloor (1323.0 $\mathrm{m}$ below sea level). However, the interlog NGT records are at slightly different depths among the various runs. The other logs have been shifted upward or downward with respect to the geochemistry-run NGT to match distinct natural gamma-ray peaks; similar corrections were performed independently by the Shipboard Scientific Party (i.e., introduction to "Downhole Measurements and Seismic Stratigraphy" report in Shipboard Scientific Party, 1993).

Calibration of the logging depth scale (meters of wireline below the rig floor) to the drill-core record was accomplished by LamontBRG by identifying the base of the suspended drill pipe (meters below rig floor) in the response of the resistivity logs. During all logging runs in Hole 878A, the drill pipe was suspended at 1529.7 mbrf, or $17.2 \mathrm{~m}$ below the 1337.6 "bottom felt depth" used to assign core depths, implying that it was $17.2 \mathrm{~m}$ into Hole $871 \mathrm{C}$. However, the response of the resistivity logs was interpreted by Lamont-BRG to indicate an apparent depth of the drill-pipe base at $1336.3 \mathrm{mbrf}$, which is $1.3 \mathrm{~m}$ higher than the $1337.6 \mathrm{mbrf}$ "bottom felt depth" used in the Initial Reports volume (Shipboard Scientific Party, 1993). Therefore, Lamont-BRG applied a depth correction of $1336.3 \mathrm{~m}$, instead of $1337.6 \mathrm{~m}$, to convert meters below rig floor of the wireline logging depths of all logs to meters below seafloor within the drill hole. This correction is identical to the 1.3-m-downward depth shift to the logs (i.e., subtraction of $1.3 \mathrm{~m}$ from recorded logging depths) made by the Shipboard Scientific Party.

There are additional complications, such as deducing the exact base of the drill pipe in the logging runs or identifying unique sharp features on the natural gamma traces for precise depth shifting. In addition, the Lamont-BRG internally adjusts the two FMS runs with respect to each other to match common features to within a few centimeters. This internal depth-shifting of FMS traces is thought to be necessary because of differential stretching of the wireline during ocean swells or variable friction within the borehole.

In this summary of logging stratigraphy, all features are described relative to Lamont-BRG-processed "corrected" FMS depths, which are the scales for the FMS imagery on the well-log data compact disk (CD-ROM) distributed with the Ocean Drilling Program Initial Reports (Premoli Silva, Haggerty, Rack, et al., 1993). In general, the FMS-depths correspond closely to the reported depths of distinctive features by the shipboard downhole measurements team.

This suite of Lamont-BRG depth adjustments to the FMS runs are at a minor variance with respect to the depth-corrected scales for the geophysics and geochemistry logging suites, and position of features may possibly be slightly different from coring depths of recovered sediments. In general, the FMS features are approximately $0.9 \mathrm{~m}$ above the depth of the same feature in the geophysics logs within most of the borehole. Other sharp features in the FMS and resistivity logs support this general depth correction, although minor "tuning" of $10-30 \mathrm{~cm}$ was required in some intervals to further place the resistivity $\log$ into exact correspondence with the FMS log. The natural gamma-ray record used in the accompanying diagrams for Site 878 is from the NGT on the same FMS string, so its depths should be consistent with depths from the FMS imagery processed by LamontBRG. In the few instances where cored lithologic features appear to be at variance in depth with the corresponding FMS features, the calibration problem is noted in the descriptions.

Regardless of the exact calibration of the various "corrected" depths, the thicknesses and spacing of all features will be identical among the borehole, the FMS imagery, and the other downhole logs.

\section{Processing of FMS Resistivity Imagery}

The FMS tool creates high-resolution images of the borehole by measuring the electrical resistivity contrast across an array of small electrodes (Ekstrom et al., 1986; Pezard and Luthi, 1988; Bourke et al., 1989; Molinie and Ogg, 1992). The Ocean Drilling Program (ODP) FMS has four orthogonal pads containing 16 pad-mounted button electrodes that are pressed against the borehole. A single run of the ODP FMS provides approximately $25 \%$ coverage of the borehole circumference. Two runs were made in Hole 879A to enable a maximum of $50 \%$ coverage of the borehole where traces did not overlap. Resolution, processing, and interpretation of FMS imagery in shallow-water carbonate facies is discussed in Ogg et al. (this volume). The examples of FMS images reproduced in the figures in this report have been "static mode" processed over a 10-m interval of the FMS record of Hole 878A, implying that the 16 shades of gray have been linearly normalized between the highest value of resistivity (white) to the lowest value (black) occurring within that interval and further enhanced using NIH Image software. Therefore, within each $10-\mathrm{m}$ interval, a particular shade of gray corresponds to the same relative resistivity, but that resistivity level may be represented by a different gray shade in the adjacent window. In order to compare resistivity trends over thicker intervals, the FMS data were also staticprocessed over 100-m intervals (see CD-ROM in Premoli Silva, Haggerty, Rack, et al., 1993) and over $360-\mathrm{m}$ portions of lower (365-737 mbsf) or upper (17-370 mbsf) FMS-logged interval of Hole 878A (available from Lamont-BRG).

\section{Geochemical Log Processing}

The geochemical records from the induced-gamma spectrum tool (GST) were converted by Lamont-BRG to relative elemental contributions by $\mathrm{Fe}$ (assuming an equal contribution by magnetite and hematite), $\mathrm{Ca}, \mathrm{Cl}, \mathrm{Si}, \mathrm{Su}, \mathrm{Ga}, \mathrm{Ti}$ and $\mathrm{H}$ (the last two elements were computed during processing), with corrections for hole diameter as 
recorded by calipers on the density tool (CALI on the HLDT) and on the FMS string (" $\mathrm{C} 1$ " and "C2"). The relative ratios of these elemental factors are more useful for lithologic trends than the less accurate elemental values for direct computation of rock-chemistry.

\section{INTERPRETATION OF CARBONATE FACIES FROM DOWNHOLE LOGS}

Our goal in analyzing the various logs is to obtain a complete record of the history of depositional environments. The major carbonate textures and composite depositional facies, such as algal-microbial mats, generally could be distinguished by their signatures on a combination of three logs: the spherical-focused resistivity log (SFLU), which measures the absolute resistivity of the borehole wall with a vertical resolution of about $75 \mathrm{~cm}$; the FMS microresistivity imagery, which indicates the "texture" and vertical successions at a subcentimeter scale; and the NGT record of the relative intensity of uranium concentration. Use of a single type of log yielded more ambiguous interpretations. These log-facies signatures were developed from comparison of logs with intervals having good recovery of the lithologies and from application of logical relationships of carbonate depositional environments. In addition, the recovered sediments in each cored interval, although generally meager, provided important controls on the interpretation of the logging signals.

In contrast to surface exposures of carbonate platforms, the majority of the MIT Guyot limestone cap has been only partially cemented. Insignificant overburden (maximum of $700 \mathrm{~m}$ ) and lack of later meteoritic influence helped preserve the original granular relationships. Indeed, some peloidal grainstone intervals were observed to have no apparent cementation, which also caused very low recovery and "washouts" during drilling. Above the basal drowning surface on the underlying clay weathering zone, there was no noticeable terrigenous influx; therefore, the downhole logs can be interpreted entirely in terms of pure carbonate facies.

\section{Resistivity Log}

Resistivity of carbonate textures progressively increases from grainstone to mudstone as the porosity is steadily diminished (e.g., Asquith, 1979; Dorfman et al., 1990). The recovered core material suggests that the initial texture or environment of deposition of the limestone also influenced the degree of diagenetic cementation, with grainstones being less cemented than micritic mudstones. As a result, the corresponding responses of the resistivity and density tools are magnified by these changes in carbonate textures.

This relationship does not apply when an episode of penetrative early cementation has taken place because of possible subaerial exposure or hiatus in deposition. Such "surfaces" with underlying partial cementation are common in intervals having pronounced development of "parasequences." In these cases, the shallower depth and presumably higher energy grainstone-packstone facies commonly underwent a greater degree of cementation and, therefore, displays an upward increase in resistivity. This high-resistivity upper bed of a cycle is overlain by a facies of very low resistivity representing the succeeding deepening phase. Another common reversal of the usual relationship of grain size and bulk resistivity was observed when thin grainstone horizons from storm-bed winnowing or redeposition are interbedded within wackestone-packstone facies; these grainstone levels appear to be preferentially cemented during later diagenesis relative to the adjacent finer grained sediment.

\section{Natural Gamma-ray Log}

Natural gamma-ray intensity (NGT or SGR) within the carbonate platform in Hole 878A is mainly a monitor of the uranium concentration; influx of clays with thorium is unimportant above the weathered volcanics.
Three distinct processes were observed to contribute to the variations in uranium natural gamma-ray intensity.

1. Uranium displays higher relative concentrations in algalcyanobacterial mats and oncolites because their reducing microenvironments are conducive to redox scavenging of uranium from seawater. Although this uranium concentration process is most effective for algal-cyanobacterial mats, it was also observed to be applicable to red-algal encrustations and concretions (rhodoliths).

2. Uranium is often enriched in limestones deposited in depositional environments in which organic matter or phosphate was originally present, because uranium from seawater is preferentially precipitated in relatively reducing conditions (Serra, 1985). Quiet-water carbonate facies, such as wackestone and mudstone, were observed to display a higher natural gamma-ray intensity than high-energy facies, such as grainstone. These mud-rich sediments, which are commonly bioturbated, probably retained a greater initial organic content in the buried sediment than the more aerated facies; therefore, uranium would be preferentially concentrated in the mud-rich facies. In this regard, minor peaks in uranium were observed to occur at levels interpreted as "maximum flooding surfaces," where the concentration of carbonate mud (and rare pelagic microfossils) and presumably fine organic material was at a maximum.

3. Uranium can be concentrated during later diagenesis at the redox interfaces between relatively oxygenated and relatively reducing interstitial water conditions. This redox enhancement was observed at the boundaries between tan- and gray-colored sediments of the same facies (such as lagoonal wackestones) and within the carbonate mud-rich transgressive sediments immediately overlying a surface of emergence or condensation. At these redox levels, the uranium was generally concentrated in a narrow horizon, in contrast to the more dispersed concentrations associated with mud- or algalmicrobial-rich facies.

\section{Formation MicroScanner}

The FMS imagery was important to determine the homogeneity of carbonate grains and cementation patterns at the centimeter scale and to compare fine-scale vertical trends in relative resistivity.

Grainstone facies typically display a uniform low-resistivity texture, displayed in the gray-scale imagery as a homogeneous dark gray interval.

Packstone to wackestone facies generally had a more uneven centimeter-scale resistivity, presumably resulting from differential abundances of carbonate mud and related extent of partial cementation during diagenesis. Therefore, the FMS imagery displays a more mottled appearance with irregular diffuse patches of higher resistivity ("light-gray mottles"). In some wackestone-packstones, especially in recovered cores in lagoonal gastropod-pellet facies, significant leaching of the larger bioclasts has created a moldic porosity within a porous wackestone matrix. The corresponding FMS imagery displays a "medium-gray," moderate-resistivity background with abundant dark (leached) spots and some diffuse patches of preferential cementation.

In facies having microbial-enhanced concentrations of carbonate mud, such as algal-microbial-mat intervals or red-algae encrustations and coral-algal banks, horizontal lenses of high-resistivity material are distributed within a low-resistivity matrix.

Rudstone (mainly beds of storm-washed rubble) or boundstone beds (not observed in the FMS logs within this lagoonal setting) display a "blocky" texture of $10-\mathrm{cm}$-scale, rounded and sharp-bordered patches of contrasting resistivity. An interpretation of "storm bed" is assigned to distinct higher resistivity or "rubble" beds with sharp bases occurring within an otherwise homogeneous wackestonepackstone facies.

Our independent calibration of carbonate textures to FMS imagery appearance is similar to the relationships observed in the logs in the carbonate platforms of the guyots drilled on the preceding Leg 
143 (Cooper et al., 1995); however, there are some minor nomenclature and implied depositional environment differences. These differences are mainly the result of the calibration of the FMS imagery to shipboard descriptions of the same sediments. For example, the "mudstone with moldic porosity" facies of Cooper et al. (1995) displays the same FMS texture as our "bioclastic wackestone-packstone" classification. The sediments recovered in this facies consist of abundant bioclastic molds in wackestone-packstone that had undergone extensive diagenetic "chalkification"; therefore, it was not initially a mudstone, and I have tried to maintain the shipboard sedimentological nomenclature of the facies before extensive diagensis.

\section{Recovered Sediments}

Recovery was typically less than $10 \%$ of each cored interval. Recovery was highest when the cored facies consisted of uniformly moderate-cemented carbonates. Neither well-cemented beds, which apparently shattered upon drilling, nor poorly cemented facies, which disintegrated under the drill, had significant recovery. Interbedded layers of variable cementation, such as occur in the shallow-water upward-shoaling facies successions or parasequences, had recovery biased toward the uppermost well-cemented bed. Similar recovery biases were noted in the Leg 143 drilling of guyots (Cooper et al., 1955). Unfortunately, an implication is that those intervals which contain a significant amount of vertical variation (hence of the most value to interpretations of changing depositional environments and possible sea-level changes) also have the lowest recovery of sediments to enable direct sedimentological interpretation of facies trends.

\section{Model of Depositional Facies}

The vertical succession of carbonate facies reflects changing depositional environments of wave energy (winnowing or deposition of carbonate mud), of ecological zones (algal mat, gastropod, etc.), and of relative water depth (emergent horizons, lime-mud enrichments etc.). Interpretation of relative shifts of facies (e.g., lagoonward versus seaward; upward-shallowing vs. deepening) requires a basic conceptual model of the original distribution and depositional environments of the various carbonate facies (Fig. 2).

Lagoonal facies present a particular problem because of the difficulty of identifying episodes of prograding coral-algal production ("carbonate factory") creating parasequences or of transgressive backstepping of seaward facies. Instead, a relative depth-facies interpretation can be made according to the relative proportion of lime-mud, the relative importance of storm events disrupting sedimentation or washing in beds of coarser debris, and the biological assemblages. However, such "deepening" and "shallowing" trends can be obscured by changes in the degree of restriction of the lagoon floor from the open sea. A "quiet" lagoon facies might imply a greater degree of restriction rather than a deeper water setting. Also, an increased abundance of storm-bed layers might reflect a greater proximity of grainstone-rudstone shoals rather than an upward-shallowing of the lagoon floor.

For placing the cored and logged facies of this Aptian-Albian platform-bank into depositional environment belts, we used a simple model that combines relative mud content and biological assemblages (e.g., Jansa and Arnaud Vanneau, this volume). We used an idealized succession from the deep "lagoon" facies deposited in relatively quiet waters and/or distant from reef-shoal barriers through the shallow "lagoon" facies or intertidal depths in the lee of barrier shoals to the "island" facies formed by storm accumulations from the seaward active carbonate-sediment factory: (1) mudstone to wackestone with small benthic foraminifers; (2) wackestone-packstone with gastropods and miliolid foraminifers; (3) packstone, which may contain layers of storm-redeposited or winnowed in situ grainstone or rudstone; (4) algal-rich facies, which may contain algal-concretions (oncoids or rhodoliths) in packstone-grainstone, and generally has an associated concentration of uranium producing an elevated natural gamma-ray intensity; (5) winnowed grainstone of various bioclasts and foraminifers, or partially cemented packstone with fenestral features of possible intertidal or algal mat origin; (6) emergent grainstone-rudstone shoal or island of coarse storm-redeposited debris from the seaward "carbonate factory"; and (7) coral-algal reef flat.

This conceptual model of relative lagoonal depth is partially based on comparisons with Tertiary atoll lagoon settings and Early Cretaceous carbonate seaways. However, the "lagoonal" facies may also be developed in interiors of platforms like the Bahama Banks which have a partial barrier (reefs and shoals) only on the windward side. It is not certain that these Cretaceous guyots had a true atoll morphology during much of their development. Therefore, "lagoon" is used here in a broad sense as a partially protected interior of the carbonate bank.

Algal-cyanobacterial mats and oncoids have a wide depth range. In Hole 878, these microbial features (often generalized as "algal" in the following descriptions, even though cyanobacteria play the major role) commonly are associated with a packstone-grainstones facies, which we generally interpret to represent a shallower depth than a lime-mud-rich facies. However, a transition from a skeletal wackestone with fenestrae features to an oncoid packstone would imply a deepening trend.

Carbonate platform facies of all geological ages typically have upward-shallowing cycles or parasequences superimposed upon larger scale trends. A "parasequence" is defined as "a relatively conformable succession of genetically related beds or bedsets bounded by marine flooding surfaces or their correlative surfaces ... separating younger strata from older strata across which there is evidence of an abrupt increase in water depth" (Van Wagoner et al., 1990). These parasequences or upward-shallowing facies successions are typically of meter-scale thicknesses and have recurrence periodicity similar to Milankovitch orbital-climate cycles, although the exact causes of the cyclicity are debated (e.g., reviews in Wilson, 1975; Tucker and Wright, 1990; Jones and Desrochers, 1992; Pratt et al., 1992). A few intervals within Hole $878 \mathrm{~A}$ were dominated by repetitious, $\sim 5-\mathrm{m}$ thick cycles of upward-increasing resistivity sharply terminated to the lower resistivity base of the following cycle. These cycles were dominant when the depositional environment was "shallow lagoon to intertidal," and typically incorporated the upward-shallowing suite of uncemented wackestone-packstone to algal-rich carbonate to relatively well-cemented packstone-grainstone. The associated FMS imagery and natural gamma-ray characteristics indicated that the uppermost high-resistivity zone of each cycle appeared to be a cemented grainstone, which we interpret as a downward cementation episode associated with an emergence or condensation horizon on a shallow shoal of grainstone debris. In these cases, the upward-increasing resistivity is not the result of an increased carbonate mud component, but caused by an anomalous cementation level. However, similar upward-increasing resistivity cycles were interpreted as "upwardfining sequences" in the borehole logs into lagoonal facies of Cretaceous guyots drilled on Leg 143 (Cooper et al., 1995).

The duration of individual parasequences in Hole 879A appears to be near the $100,000 \mathrm{yr}$ Milankovitch period of eccentricity modulation of precession. This Milankovitch cycle produces cyclic changes in global climate and ocean fertility and temperature (e.g., Molinie and Ogg, 1992a, 1992b). The predicted magnitude of these Milankovitch-induced oscillations of sea-level in nonglacial intervals is probably equivalent to the combined effect of ocean thermohaline volume changes $(\sim 0.1-10 \mathrm{~m}$, depending upon the magnitude of cyclical heating and cooling of deep ocean waters) and postulated changes in groundwater storage on the continents (up to 10-20 m). During stillstands or periods of falling sea level, these Milankovitch-cycle oscillations of global sea level will produce a series of stacked, condensed, upward-shallowing successions or parasequences. During long-term transgressions, these oscillations produce rapid upward pulses of sea-level interspersed with relative stillstands. 


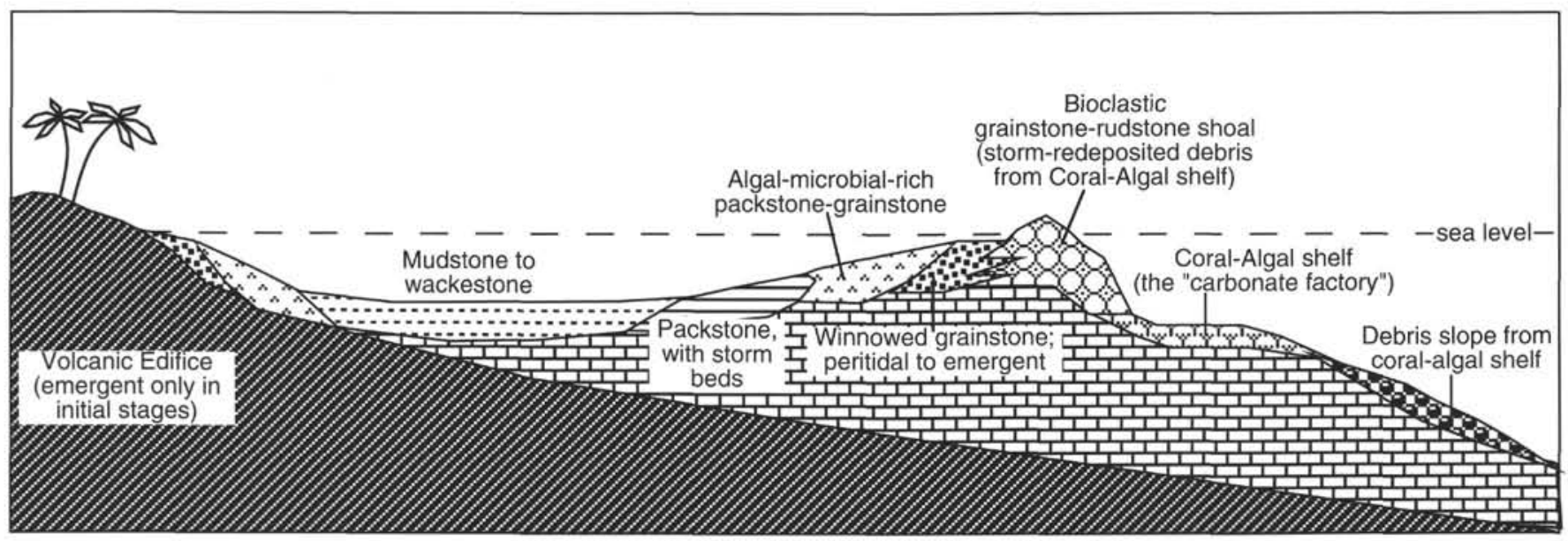

Figure 2. Idealized model of carbonate facies across a guyot platform. A quiet-water lagoon forms in the lee of shoal deposits of wave-redeposited bioclastic debris. Algal-cyanobacteria features and storm reworking occur preferentially in the shallower depths of the lagoon. A typical transgressive facies succession during initial submergence of the former volcanic island is wave-winnowed grainstone, algal-or oncoid-rich packstone, and lime-mud-rich lagoonal sediments.

\section{INTERPRETATION OF DEPOSITIONAL HISTORY}

The following depositional history of the carbonate facies integrates the independent observations from the cored sediments (typically $0.2-1.0 \mathrm{~m}$ of recovery from each $10-\mathrm{m}$ cored interval), the quantitative resistivity measurements, the variation in natural gamma-ray intensities and associated uranium/thorium/potassium abundances, and the detailed FMS records of "textures" and vertical successions. Division of the lithologic succession into subunits was based initially upon the facies and nomenclature of shipboard-defined lithologic units. At Site 878, the two carbonate platform successions were denoted by the shipboard sedimentologists as lithologic Units $\mathrm{V}$ and III-II and further subdivided into lettered subunits. The continuous downhole logging records enabled improved resolution of the boundaries or transitions between these lithologic subunits (Table 1) and allowed additional subdivisions to be defined as coherent log-facies packets or as major parasequences (Fig. 1, back pocket). Summaries of the recovered lithologies of these subunits and details of the signatures and interpretation of possible depositional facies for the associated downhole logging subdivisions are compiled in the Appendix.

Two important assumptions are required for this interpretation of the depositional history of Site 878 . First, it is assumed that the logging characteristics and associated core recovery are representative of an unambiguous facies and associated depositional environment. Jansa and Arnaud Vanneau (this volume) have independently obtained a depositional history of MIT Guyot which is based mainly on the recovered facies. The broad outlines of their interpretation are similar to this study; however, the details differ significantly in many intervals because I have relied heavily on the high-resolution FMS imagery to constrain interpretations of facies where core recovery is meager or nonexistent.

Second, it is assumed that the facies within Hole $878 \mathrm{~A}$ reflect large-scale trends within the central portion of MIT Guyot, rather than local shifts and isolated patterns of environments. The assumption of local versus general facies trends is particularly important for the interpretation that upward-shallowing parasequences reflect eustatic sea-level fluctuations rather than autocyclic behavior of the carbonate system. The interpretation of carbonate upward-shallowing cycles within isolated outcrops or logging data is debated (e.g., Osleger, 1991; Drummond and Wilkinson, 1993a, 1993b; Goldhammer et al., 1993; Grötsch, 1994). However, most regional studies have concluded that the major facies trends and sets of parasequences within a single outcrop are indicative of larger scale patterns of facies shifts and carbonate sequence system tracts, rather than an artifact of random or autocyclic facies changes (e.g., Goldhammer et al., 1990; Van
Wagoner et al., 1990; Osleger and Read, 1993; Gräfe and Wiedmann, 1993). Therefore, the major deepening or shallowing trends interpreted within Hole $878 \mathrm{~A}$ are considered to be indicative of broader facies trends within the central portion of the MIT Guyot carbonate platform, and it is assumed that these trends provide a monitor of relative sea-level changes with respect to the platform.

\section{Submergence of the Volcanic Edifice and Formation of a Protected Lagoonal Environment (727.5-684.0 mbsf; Logging Facies Subunits VB-1 through VA-2; early Aptian)}

The initial drowning of the volcanic complex was preceded by an interval of subaerial weathering. The uppermost volcanic flows are interbedded with and capped by clay-rich zones attaining $1.5 \mathrm{~m}$ in thickness. The onset of carbonate sedimentation $(727.5 \mathrm{mbsf})$ is marked by a sharp contact to the underlying partially altered basalt, and it is possible that this contact represents a transgressive hiatus accompanied by wave scour and removal of the former soil or shoreline environments of the volcanic island. The initial submergence may have been caused primarily by the rapid subsidence of the volcanic edifice, rather than a flooding associated with a global eustatic sea-level rise. The transgressive drowning was sufficient to isolate Site 878 from any further sedimentation from emergent volcanic islands. There is no detectable influx of terrigenous clay or associated enhanced levels of thorium, aluminum or silica within the core recovery or geochemical logs.

The lowest carbonate sediment is a 6.5 -m interval of skeletal grainstone with peloids, oolites, and red algal fragments including rhodoliths (Subunit VB-1). This set of partially emergent carbonate-sand shoals or bars was formed by wave-reworked debris from the seaward carbonate factory, but has some in situ growth of algal rhodoliths. One or two episodes of significant emergence, which may be associated with the lowstand portions of parasequence cycles, resulted in a yellow to red staining of the grainstone, two levels of enhanced cementation, and redox concentration of uranium. At this stage, MIT Guyot probably consisted of isolated volcanic islands ringed by an offshore barrier of low carbonate-sand islets, shallow algal flats and oolite bars. There are no indications of a barrier reef or significant bioherm accumulations. The seaward carbonate factory produced abundant bioclastic debris, but did not construct a framestone bulwark.

A second drowning episode ( $721.0 \mathrm{mbsf}$ ) led to establishment of an algal-rich facies with rhodoliths and/or encrustations interspersed with storm beds (Subunit VB-2,20 m thickness). The algal-rich facies intervals are interpreted from textural characteristics in the FMS 
Table 1. Lithologic subunit boundaries in Hole 878A assigned from FMS imagery and other borehole logs compared to shipboard assignments from core recovery.

\begin{tabular}{|c|c|c|c|c|c|}
\hline $\begin{array}{l}\text { Unit or } \\
\text { subunit }\end{array}$ & $\begin{array}{c}\text { Lithology } \\
\text { (brief summary) }\end{array}$ & $\begin{array}{c}\text { Base in } \\
\text { borehole } \\
\text { (mbsf) }\end{array}$ & $\begin{array}{l}\text { Thickness } \\
\text { (m) }\end{array}$ & $\begin{array}{c}\text { Shipboard } \\
\text { assignment } \\
\text { (core, section, } \\
\text { interval [in } \mathrm{cm} \text { ) }\end{array}$ & $\begin{array}{c}\text { Shipboard } \\
\text { estimate } \\
\text { of base } \\
\text { (mbsf) }\end{array}$ \\
\hline I & Pelagic ooze & $\sim 3.2$ & 3.2 & IR-CC, 0 & 3.2 \\
\hline IIA & Gastropod wackestone & 55.4 & 52.2 & $8 \mathrm{R}-1,26$ & 67.3 \\
\hline IIB & Peloid-algal wackestone to grainstone (peritidal cycles) & 83.7 & 28.3 & $10 \mathrm{R}-1,0$ & 86.2 \\
\hline IIC & Gastropod-peloid wackestone with an algal- and rudstone-rich interval & 196.7 & 113.0 & $22 \mathrm{R}-1,0$ & 202.2 \\
\hline IID & Cycles of gastropod-peloid wackestone to algal-rich grainstone & 243.5 & 46.8 & $26 \mathrm{R}-1,17$ & 236.1 \\
\hline IIIA & Peloid-foraminifer grainstone; sponge-algal and rudist bioherms; algal-rich beds & 312.8 & 69.3 & $34 \mathrm{R}-1,5$ & 312.6 \\
\hline IIIB & Peloid grainstone & 392.2 & 79.4 & $42 \mathrm{M}-1,0$ & 389.8 \\
\hline IIIC & Foraminifer wackestone and mudstone & 404.7 & 12.5 & $43 \mathrm{M}-1,43$ & 399.7 \\
\hline IVA & Clay, bluish gray & 405.4 & 0.7 & $44 \mathrm{M}-1,0$ & 406.1 \\
\hline IVB & Breccia of volcanic and limestone clasts & 513.2 & 107.8 & $56 \mathrm{R}-2,140$ & 514.7 \\
\hline IVC & Breccia of volcanic and limestone clasts & 602.5 & 89.3 & $65 \mathrm{R}-6,23$ & 604.3 \\
\hline VA & Peloid foraminifer wackestone with algal-rich intervals & 700.9 & 98.4 & $76 \mathrm{R}-1,0$ & 703.0 \\
\hline VB & Skeletal-oolitic grainstone with algal rhodolith & 727.5 & 26.6 & $78 \mathrm{R}-1,44$ & 722.5 \\
\hline
\end{tabular}

imagery (Fig. 3) and the associated concentrations of uranium. However, the core recovery is dominated by the reworked bivalve-coral rudstone and carbonate sands of coated skeletal grains. This preferential recovery within a cored interval of the lithologies that are more granular and homogeneous was a common feature during the Leg 144 drilling operations. Pieces of cross-laminated oolite beds were also recovered from this subunit, but these beds do not seem to be significant in the FMS imagery. This assemblage of facies presents a picture of a shallow, partially restricted platform interior with patches of bivalve-coral accumulations, which may be somewhat analogous to the present Bahama platform "lagoon." Wave and storm redistribution of bioclastic rubble followed by partial algal encrustation is the dominant sedimentation process.

The next major phase of deepening (700.9 mbsf) established a protected to partially restricted lagoon. A thin-bedded interval of mudstone-wackestone (Subunit VA-1, 1 m thickness) is overlain by nerineid-gastropod-peloid wackestone with episodes of storm reworking (Subunit VA-2, $16 \mathrm{~m}$ thickness). The uppermost $7 \mathrm{~m}$ of Subunit VA-2 displays a texture in the FMS imagery interpreted as partially cemented wackestone-packstone and/or rudstone. An increase in uranium content suggests an algal component. Carbonate facies with a high mud content and a low-diversity fauna dominated by gastropods are characteristic of protected to restricted platform or lagoon settings (e.g., Wilson, 1975). The sharp transition between the open platform suite of Subunit VB and the quiet-water facies of Subunits VA-1 and VA-2 can be interpreted as a transgressive condensation, and the mudstone beds may have been deposited during the maximum deepening. The presence of planktonic foraminifers and calcareous nannofossils at the base of Subunit VA-1 (base of Core 144-878A$75 R$ ) suggests that a deepening event preceded the establishment of a protected lagoon (Shipboard Scientific Party, 1993). There is no indication that this protected lagoon had hypersaline conditions, therefore only a partial restriction was present. A possible analogous environment at this stage of MIT Guyot may be the back-barrier mud- and mollusk-rich facies of modern Florida Bay (e.g., Tucker and Wright, 1990), rather than the deep lagoons of modern atolls.

This trend of drowning and development of progressively deeper and more protected depositional environments indicates a transgressive systems tract. The stabilization of the quiet-water lagoon environment and increased abundance of algae within Subunit VA-2 may be associated with the early phase of the highstand systems tract.

\section{Upward-shallowing Trend to Dominance of Algal-rich Parasequences (684.0-623.5 mbsf; Logging Facies Subunits VA-3 through VA-6; early to late Aptian)}

The platform becomes dominated by a "Bahama-type" facies assemblage of algal-coral accumulations, algal bindstones, winnowed grainstones, and gastropod-peloid wackestones. The lower third (Subunit VA-3) of this 60-m interval has algal-coral to algal-stromatoporoid horizons interbedded with winnowed platform-derived grainstones of coral-mollusk fragments and/or ooids and peloids. This interbedding produces meter-scale bedding of contrasting resistivity and uranium content, but no well-defined upward-shallowing cycles. However, a piece of fenestral-bearing wackestone in Core 144-878A-72R suggests that intertidal depths were attained for at least a brief time in the upper portion of this unit. The abundance of grainstone intervals indicates more open-marine conditions compared to the preceding protected conditions of Subunit VA-2.

Partially protected conditions and deposition of relatively mudrich and algal-rich facies characterize the 16-m-thick Subunit VA-4. Levels of algal-stromatoporoid boundstone are indicative of a shallower and more restricted setting. This interval also corresponds to the episode of less oxygenated marine paleoecologic conditions interpreted by the abundance of ostracods, and of miliolid and Valvulineria foraminifers (Shipboard Scientific Party, 1993).

A minor deepening led to quiet-water lagoon conditions characterized by miliolid foraminifer and peloid wackestone with rare gastropods (Subunit VA-5, $18 \mathrm{~m}$ thickness). The upper portion of this interval exhibits multi-meter cycles of upward-increasing resistivity sharply overlain by the low-resistivity base of the following cycle.

These cycles, interpreted as upward-shallowing parasequences, characterize the overlying facies (Subunit VA-6, $5 \mathrm{~m}$ thickness). Three parasequences are developed in a relatively well-cemented, algal-flat to grainstone shoal facies, but there are no unambiguous indicators of episodes of emergence. Upward-shallowing parasequences observed in other holes drilled during Leg 144 are typically $4-5 \mathrm{~m}$ thick, whereas the parasequences in this interval of Hole $878 \mathrm{~A}$ are only about $2 \mathrm{~m}$ thick. Shallow-water Subunit VA-6 is terminated at $623.5 \mathrm{mbsf}$ by a rapid return to open-marine lagoonal conditions (Fig. 4).

In general, these subunits represent a progressive shallowing or infilling of the protected lagoon. Therefore, the lower $55 \mathrm{~m}$ of this interval are considered to represent a highstand systems tract. The rapid shallowing and onset of well-developed parasequences in the upper portion of Subunit VA-5 is interpreted to contain a sequence boundary (approximately $628.3 \mathrm{mbsf}$ ). The shallow-water facies and relatively thin upper parasequences of Subunit VA-5 may have formed when sea level was falling at a rate only slightly slower than subsidence, therefore may be equivalent to "lowstand" system tracts in regions of slower subsidence. Subunit VA- 6 is terminated by a rapid deepening $(623.5$ mbsf) and onset of transgressive system tract deposition. Within this main highstand systems tract are two minor cycles of deeper facies (Subunits VA-3 and VA-5) and shallower facies (Subunits VA-4 and VA-6).

\section{Deepening Episode and Early Stages of Volcanic Reactivation (623.5-602.5 mbsf; Logging Facies Subunits VA-7 and VA-8; early to late Aptian)}

The deepening surface at $623.5 \mathrm{mbsf}$ is the termination of algalenrichment for this lower carbonate platform (Fig. 4). The restricted 


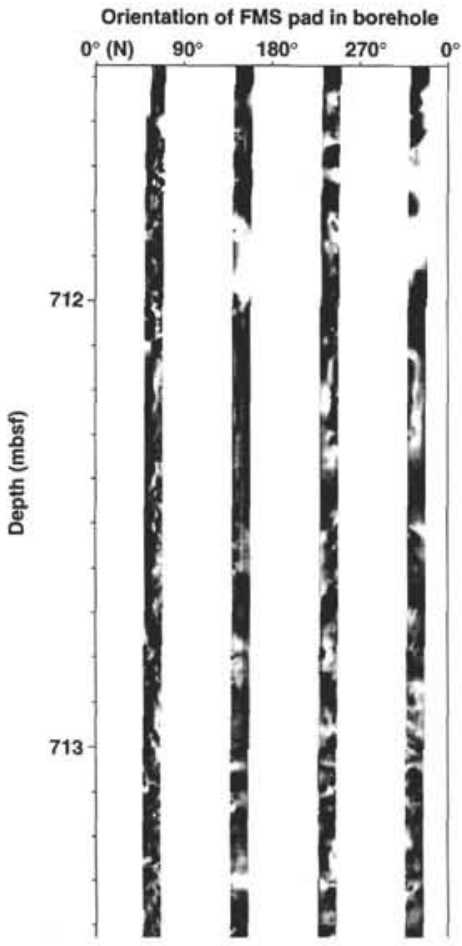

Figure 3. FMS static-processed image from the middle portion of loggingfacies Subunit VB-2 of shallow-water, skeletal-oolitic grainstone facies, rich in algal rhodoliths or algal encrustations. This interval (711-714 mbsf, corresponding approximately to Core 144-878A-76R) is of early Aptian age. Subunit VB-2 is characterized by a granular FMS texture with abundant high-resistivity blocks or lenses, which, when coupled with the high natural gamma-ray intensity, are interpreted to be rhodoliths or algal encrustations within a grainstone. In this and all following FMS images, the high-resistivity beds are shown in white and low-resistivity beds are in black; the gray-scale contrast for relative resistivity has been maximized over the displayed image interval using NIH Image software; the orientation of the four FMS traces is clockwise around the borehole, with magnetic north on the left edge fixed by a borehole magnetometer in the FMS tool; the borehole circumference is approximately $1 \mathrm{~m}$.

shallow-water facies of Subunit VA-6 is overlain by $17 \mathrm{~m}$ of winnowed grainstone with rare rudstone beds (Subunit VA-7). These poorly cemented grainstones consist of mollusk fragments, coated grains and possibly rare ooids. Analogous modern settings may be the barren carbonate sands blanketing the modern Truk and other large atoll lagoons or the extensive lime sand belt inshore of the margin of the modern Florida Key rimmed-shelf (e.g., Tucker and Wright, 1990).

The uppermost granular facies of the lower Aptian carbonate platform (Subunit VA-8, $4 \mathrm{~m}$ thickness) is an intraclast-bearing peloidoolite grainstone interrupted by two thin $(10 \mathrm{~cm}$ thick) horizons of low resistivity. These unusual low-resistivity beds have sharp contacts with the adjacent limestone, and are interpreted to be volcanic ash layers that herald the approach of the following massive eruption. There are no unambiguous indications of upward-shallowing parasequences or other lithologic evidence of shallow-water conditions. The enhanced cementation and limonite staining of the limestone beds adjacent to these volcanic clays were probably caused by diagenesis rather than emergence. The depositional environment before the volcanic catastrophe is considered to be a continuation of the underlying back-barrier winnowed sands and storm beds of Subunit VA-7 (Fig. 5).

These subunits are interpreted to be transgressive to early highstand systems tracts that were deposited over the previous shallowwater algal-rich facies. It is not possible to determine if the carbonate platform was uplifted by the approaching major volcanic event.

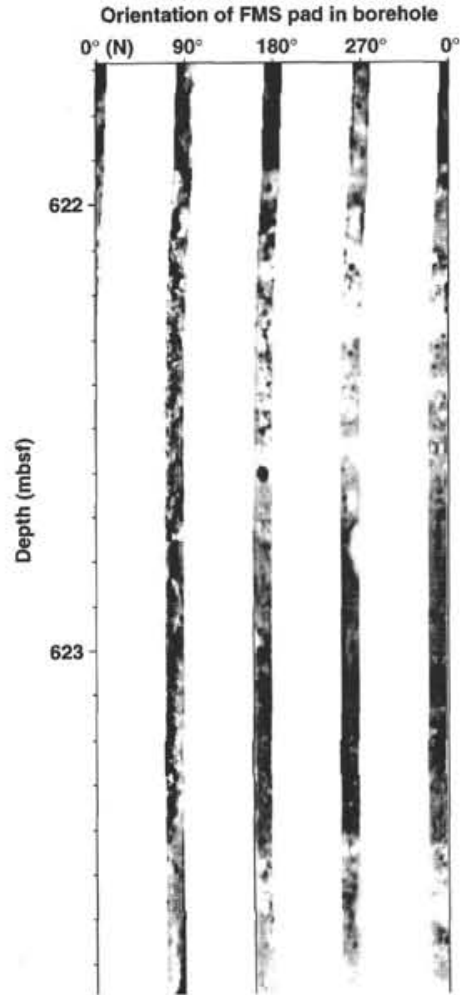

Figure 4. FMS static-processed image of the transition (623.5 mbsf) from algal-rich Subunit VA-6 to Subunit VA-7 of open-lagoon grainstone-packstone. This interval (622-624 mbsf, corresponding approximately to Core 144-878A$67 R$ ) is of early Aptian age. Subunit VA-6 has cycles of upward-increasing resistivity that are sharply terminated by the next low-resistivity base of the next cycle and that have a texture which is similar to "algal" and grainstone facies of lower units. Zone at $623.7 \mathrm{mbsf}$ has thin-bedded "algal encrustation" appearance. Subunit VA-7 is characterized by granular texture, but with abundant 1- to 2-cm diameter spots or mottles of higher or lower resistivity. High-resistivity layer at $622 \mathrm{mbsf}$ has a rubble-like appearance; this may be a storm event or a final algal-enriched episode underlying the main lagoonal grainstone-packstone facies of Subunit VA-7. Format of FMS image is explained in Figure 3.

\section{Catastrophic Volcanic Eruptions, Subaerial Weathering, and Submergence (602.5-404.7 mbsf; Lithologic Unit IV; late Aptian)}

In the middle of the Aptian, MIT Guyot was devastated by two major explosive volcanic eruptions, which transformed a large portion of the carbonate platform into enormous quantities of ejecta of intermixed carbonate and volcanic clasts. The interior platform setting at Site 878 was buried beneath $200 \mathrm{~m}$ of steaming volcaniclimestone breccia derived from these volcanic blasts. Nearly half of the clasts, which are typically less than $2 \mathrm{~cm}$ in diameter, and most of the fine-grained matrix of this breccia pile are from former lower Aptian limestone deposited during the first phase of carbonate platform development. These limestone clasts include miliolid foraminifer wackestone, peloid packstone, and ooid grainstone. This suite of lithologies is similar to those in the lower platform in Hole 878A, indicating that the site of these volcanic eruptions was beneath a portion of MIT Guyot platform formed by open-marine inner ramp to quiet-water lagoon environments.

The breccia pile displays irregular large-scale cross-bedding in the cores and FMS imagery, with the fluctuating dips averaging approximately $15^{\circ}$ toward the southwest to southeast. This dip direction suggests that the source of the debris and explosive eruptions was 


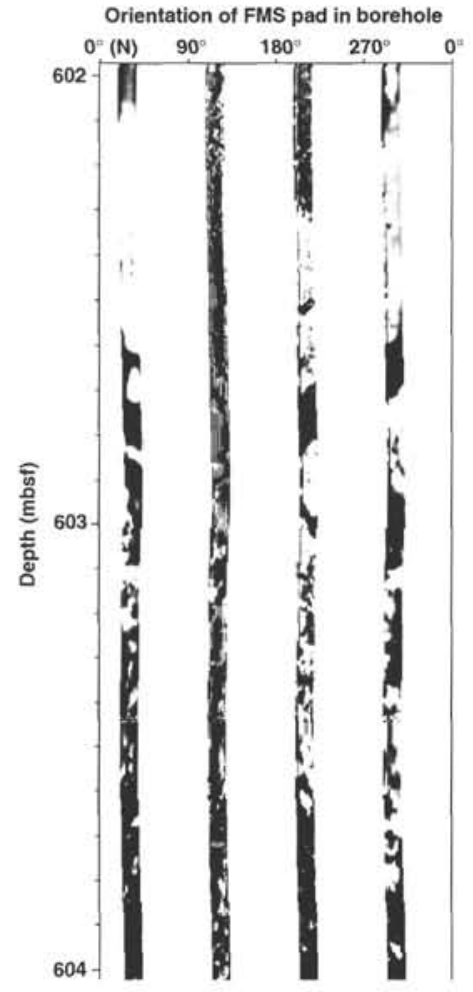

Figure 5. FMS static-processed image of the termination of the early Aptian carbonate platform (Subunit VA-8) by the initial phase of volcanic-rich debris deposition (Subunit IVC-1). This interval (602-604 mbsf) corresponds to the lower portion of Core 144-878A-65R. Subunit VA-8 has a medium to high resistivity with a rubble appearance in some beds. Format of FMS image is explained in Figure 3.

north of Site 878 , perhaps associated with the elongate "handle" of the northeast extension of MIT Guyot.

A higher carbonate content of the volcanic-limestone mixture, especially the percentage of lime mud in the matrix, corresponds to an increased resistivity of the breccia. This observed relation can be used to diagnose the eruptive phases and presumed widening of the throat of the eruption through the earlier carbonate platform. There were two main eruptions (Subunits IVC and IVB), depositing 89 and $108 \mathrm{~m}$ of breccia, respectively.

The initial blast of the first eruption deposited an increasing abundance of large limestone clasts (Subunit IVC-1, $25 \mathrm{~m}$ thickness), indicating excavation and enlargement of a crater into the limestone platform. The resistivity and carbonate content are suddenly decreased (577 mbsf), and after an interval of fairly constant abundance of volcanic-carbonate mixture (Subunit IVC-2,37 m thickness), the eruptive sequence becomes progressively more enriched in volcanic material (Subunit IVC-3, $27 \mathrm{~m}$ thickness). The top of this first eruption breccia has an irregular sharp contact to the overlying breccia episode at $513.2 \mathrm{mbsf}$. This contact does not display any evidence of clayenrichment or other indications of a weathering hiatus; therefore, the second eruption must have immediately followed the first event.

The second breccia begins with a carbonate-rich interval (Subunit IVB-1, $52 \mathrm{~m}$ thickness; Fig. 6), suggesting further widening of the excavation. As in the first blast, the waning phase of the second eruption became progressively enriched in volcanic components (Subunit IVB-2, $44 \mathrm{~m}$ thickness). The uppermost $10 \mathrm{~m}$ of the main breccia accumulation (Subunit IVB-3) is reddish colored, has relatively lower resistivity, and a lower natural gamma-ray intensity compared to the underlying greenish colored breccia. This oxidation zone and associated redox depletion of uranium and partial alteration to clay

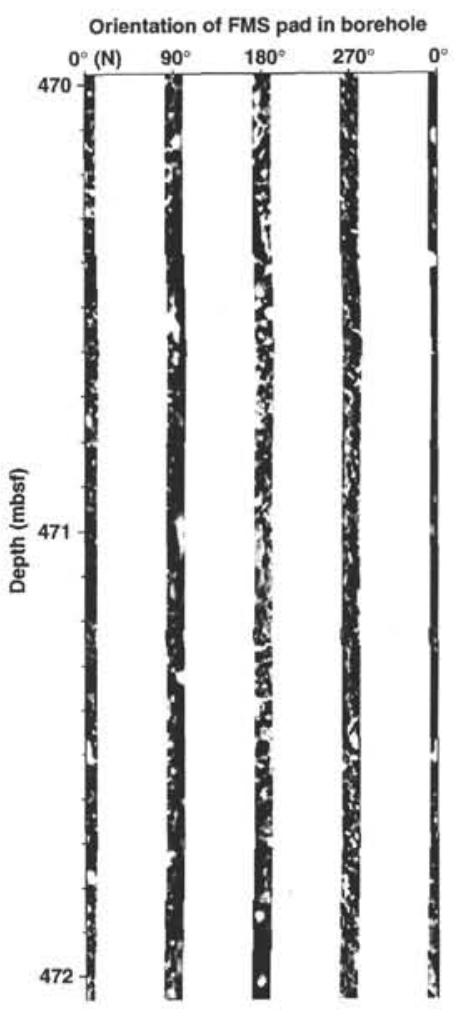

Figure 6. FMS static-processed image of typical volcanic-limestone breccia within the middle of Subunit IVB-1 (late Aptian). This interval (470-472 mbsf) corresponds approximately to Core 144-878A-51R. High-resistivity spots and blocks are predominantly limestone clasts within a volcanic-carbonate matrix. This massive subunit is over $100 \mathrm{~m}$ thick. Format of FMS image is explained in Figure 3.

minerals indicates the depth of pe stration of weathering into the volcanic breccia.

After these two main eruption blasts, there were at least three secondary ash-rich eruptions of declining intensity depositing layers of greenish volcanic tuff and associated fine-grained volcanic breccia (Subunit IVB-4, $2 \mathrm{~m}$ thickness).

The 200-m-thick volcanic breccia blanket must have transformed this portion of MIT Guyot into a large emergent island. Pervasive oxidation, probably associated with subaerial weathering, penetrated up to $12 \mathrm{~m}$ into the breccia before continued subsidence of the edifice renewed marine conditions during the middle of the late Aptian.

The lowest marine sediments are $70 \mathrm{~cm}$ of pyrite- and organic-rich clay with an associated redox concentration of uranium (Subunit IVA). Similar organic-rich clay deposits have been observed in the initial marine flooding stage at several other sites drilled during Leg 144 , and are interpreted to have formed under marginal-marine intertidal marsh to algal mudflat conditions. The accumulation of muds rich in organic material implies a shore protected from waves by an offshore barrier. There are no indications that this fringing lagoon or estuary environment experienced hypersaline conditions.

\section{Restricted to Protected Lagoon (404.7 to 312.8 mbsf; Lithologic Subunits IIIC and IIIB; late Aptian to early Albian)}

Progressive onlap of marine conditions and associated landward retreat of the shoreline led to burial of the organic-rich muds by waveor storm-winnowed carbonate sands, followed by deepening into more quiet-water environments (Subunit IIIC, $12 \mathrm{~m}$ thickness). The lower $50 \mathrm{~cm}$ of the renewed carbonate platform sedimentation is a 
homogeneous granular bed in the FMS imagery (Fig. 7), which is interpreted to be wave-reworked bioclastic and peloid grains. Uranium enrichment within the overlying $2 \mathrm{~m}$ of granular beds suggests an algal component. The upper portion of Subunit IIIC has variable amounts of lime mud, producing meter-thick beds of relatively higher or lower resistivity with a fine-scale mottling in the FMS imagery that is commonly associated with packstone-wackestone. Core recovery was less than $5 \%$ but includes pieces of foraminifer-ostracode wackestone, peloid packstone, and mudstone indicating variable degrees of restriction (Shipboard Scientific Party, 1993).

The mud-rich facies is overlain (Fig. 8) by a thick deposit of homogeneous, poorly cemented, peloid grainstone with rare bivalve and echinoderm fragments (Subunit IIIB-1, $36 \mathrm{~m}$ thickness). Peloid grainstones are generally associated with a restricted shelf or lagoon environment where organic pellets of lime mud are produced by shrimp or other burrowing or grazing organisms (e.g., Wilson, 1975; Jones and Desrochers, 1992). No storm beds, algal enrichments, or other features are preserved in these loose sands. Pellet sands are common across the broad "middle shelf" environments of the interior Great Bahama Bank in moderate to shallow water depths, especially in the lee of islands (e.g., reviews in Wilson and Jordan, 1983; Tucker and Wright, 1990; Jones and Desrochers, 1992). The transition between lime-mud-rich to lime-mud-poor sediments may indicate either a relative shallowing or that the lime-mud component could now be washed further across the MIT Guyot platform. The base of this carbonate sand interval (Core 144-878A-41M) contains planktonic foraminifers and nannofossils of late Aptian (late Gargasian substage and Rhagodiscus angustus nannofossil Zone NC7). If the Bahama model can be applied to MIT Guyot, then the onset of the carbonate sand may represent a shift from a fringing quiet-water lagoon bordering a large volcanic-breccia island into a more open exchange with the ocean on the opposite side of the MIT platform. However, the low abundance and diversity of fauna within the majority of the peloid grainstone facies suggest elevated salinities.

A shift to more normal salinity conditions may have led to deposition of the peloid grainstone with an increased component of foraminifers, mollusk fragments, and worm tubes (Subunit IIIB-2, $22 \mathrm{~m}$ thickness). This facies also displays subtle, 3- to 4-m-thick, sharpbounded variations in resistivity, which may be a moderate-depth expression of upward-shallowing parasequences. This facies is overlain by poorly cemented, homogeneous, peloid grainstone (Subunit IIIB-3, 21 m thickness), similar to the underlying Subunit IIIB-1.

This facies assemblage implies that partial to fully restricted lagoonal conditions were sustained for about $90 \mathrm{~m}$ of carbonate platform deposition. In contrast to the lower Aptian platform, there is no preserved evidence for significant algal-rich environments or storm redeposition. Following the initial transgression onto the volcanic debris banks, the depositional environment remained in a protected back-barrier setting with normal to perhaps slightly elevated salinity. This facies assemblage is assigned to a transgressive and highstand systems tract, although the transgressive portion may be entirely a response to subsidence of the edifice, rather than a eustatic rise in sea levels.

\section{Upward-shallowing Trend to Dominance by Algal-rich Parasequences (312.8-196.7 mbsf; Lithologic Subunits IIIA and IID; early to middle Albian)}

Subunit IIIA-1 is a 6-m-thick sponge-algal mound with algal rhodoliths and encrusting calcisponges in thin beds to tabular lenses. This bioherm is overlain by $21 \mathrm{~m}$ of peloidal and foraminifer grainstone with local concentrations of algae and/or macrofossils (Subunit IIIA-2). A second bioherm (Subunit IIIA-3) consists of $2 \mathrm{~m}$ of abundant bivalves, possible rudists, and gastropods within the peloidforaminifer grainstone. The very high resistivity and sharp upper surface of this bioherm suggest that it may have undergone enhanced cementation associated with a brief emergence. These two bioherm episodes are considered to be isolated patches within the general plat- form interior, rather than major shifts of the seaward carbonate factory, because there are no indications of wave-reworked rubble accumulations or other open-circulation features. Therefore, these episodes are interpreted as local variation of shallow-water facies with isolated algal-sponge or bivalve accumulations, rather than largescale sea-level changes.

Lagoonal conditions returned with another interval of the homogenized foraminifer-peloid grainstone (Subunit IIIA-4, 9 m thickness). The onset of beds of coarse, blocky material (Subunit IIIA-5, $13 \mathrm{~m}$ thickness) is interpreted to be accumulations of storm-redeposited or wave-winnowed bioclastic rudstone interspersed with the peloid grainstone. Evidence that these reworked beds represent a general shallowing trend, rather than a less protected depositional setting, is indicated by the overlying thin tabular lenses of algal-rich packstone and beds of rudist rudstone (Subunit IIIA-6, 6 m thickness). Storm-redeposition of coarse debris became the dominant sedimentation process, producing shoals of bioclastic rudstone (Subunits IIIA-7 and IIIA-8, $12 \mathrm{~m}$ total thickness). The upper portion of this debris shoal is very well cemented (highest resistivity within Hole $878 \mathrm{~A}$ ), displays a depletion in uranium, and terminates in a sharp top (Subunit IIIA-8, 2 m thickness; Fig. 9). These characteristics indicate an episode of emergence and oxidation. The drowning of this island (243.5 mbsf) marks the base of lithologic Unit II.

This upward-shallowing trend of Subunit IIIA represents the late stages of a highstand systems tract. The rapid shift at about $275 \mathrm{mbsf}$ from a protected lagoon with grainstones with isolated bioherms to a storm-influenced lagoon may indicate an overall shallowing of the depositional setting. The emergent surface on the debris island (Fig. 9) is tentatively assigned as a sequence boundary. The drowning of the debris island is associated with deposition of a foraminifer wackestone horizon with a sparse late Aptian or Albian planktonic foraminifer assemblage.

Subunit IID consists of about 12 major cycles of upward-increasing resistivity, typically terminating against the lower resistivity base of the next cycle. Each of these parasequences, averaging $4 \mathrm{~m}$ in thickness, encompasses a variety of lithologies. FMS imagery and uranium contents indicate that the typical parasequence is an upwardshallowing succession from gastropod-peloid wackestone to stormredeposited rudstone to algal-rich grainstone facies. The succession of associated depositional environments for the idealized parasequence is a protected lime-mud-rich moderate-depth lagoon followed by a storm-affected shallow-depth lagoon overlain by a shallow algal flat or accumulation of storm-redeposited rubble. The top of each parasequence is typically either a drowning surface or a rapid transition to the next deep-water phase.

The thickness and facies of the parasequence succession do not display any apparent trends. Therefore, the short-period oscillations are superimposed on either a stable stillstand or a smooth linear large scale trend in sea level. The termination of the parasequences by a deepening to a protected lagoon facies suggests that these cycles represent oscillations of sea level during the "lowstand" that followed the sequence boundary at the top of Subunit IIIA. These short-term upward-shallowing parasequences may be related to climatic-oceanographic cooling cycles associated with the $100,000 \mathrm{yr}$ Milankovitch cycle of eccentricity modulation of precession. If so, then the 4-m average thickness of these upward-shallowing cycles would imply a sediment accumulation rate of $4 \mathrm{~m}$ per $100,000 \mathrm{yr}$, and a corresponding duration for Subunit IID of about $1.2 \mathrm{~m}$.y. If this sediment accumulation rate also represents the mean subsidence rate for MIT Guyot, then the $720 \mathrm{~m}$ platformbreccia-platform succession spans about $18 \mathrm{~m}$.y. This $40 \mathrm{~m} / \mathrm{m}$.y. subsidence rate is comparatively rapid for seamounts constructed on older oceanic crust (e.g., Detrick and Crough, 1978; Larson, this volume), but it may represent an accelerated subsidence induced by the underlying major volcanic eruption episodes. If an average subsidence rate of $30 \mathrm{~m} / \mathrm{m}$.y. is assumed for the entire MIT platform succession, then the corresponding age span is about $24 \mathrm{~m}$.y., or approximately from early Aptian to middle-late Albian. This age span is consistent with the 


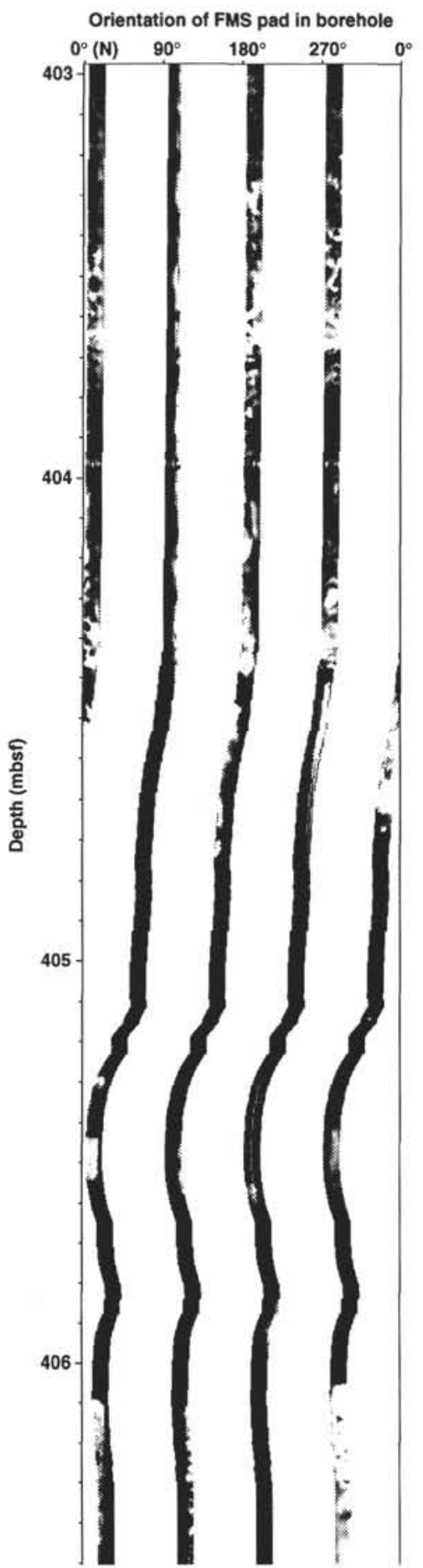

Figure 7. FMS static-processed image of volcanic tuffs of Subunit IVB-4 (405.4-407.1 mbsf, distorted in upper portion), pyrite-rich claystone of Subunit IVA (very low-resistivity bed at $404.7-405.4 \mathrm{mbsf}$ ), and the lower portion of lime-mud-rich quiet lagoon facies of Subunit IIIC. This interval (403-406 mbsf, corresponding approximately to Core $144-878 \mathrm{~A}-43 \mathrm{M}$ ) is of late Aptian age. The set of three volcanic tuffs is progressively thinner and of lower resistivity. The lower portion of Subunit IIIC (above $405.4 \mathrm{mbsf}$ ) is a mediumresistivity facies with a granular texture with sporadic high-resistivity patches or mottles, interpreted as storm- or wave-winnowed grainstone washed onto the underlying clay. Format of FMS image is explained in Figure 3.

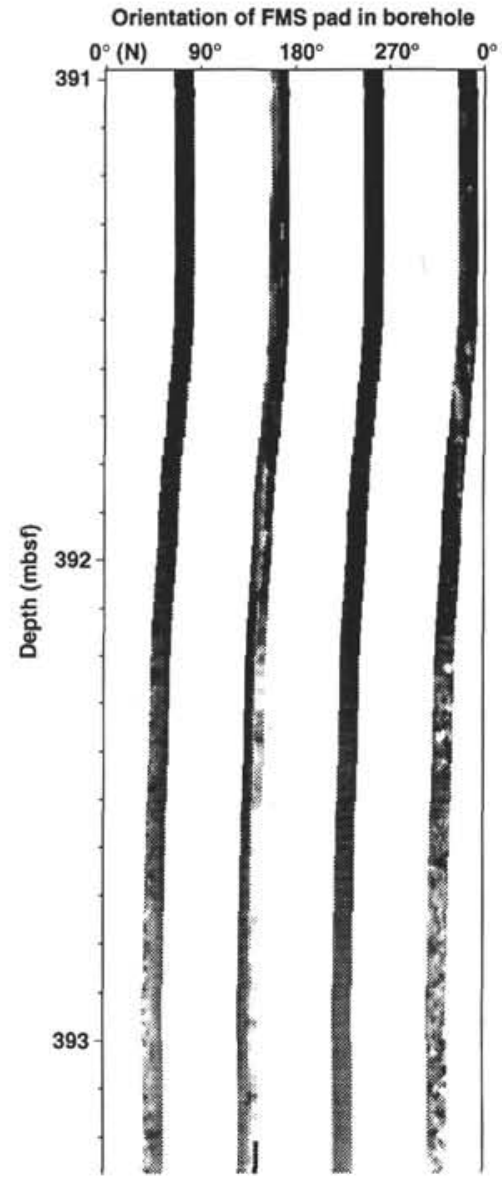

Figure 8. FMS static-processed image of the transition (at about $392.2 \mathrm{mbsf}$ ) from the quiet lagoon facies of wackestone in Subunit IIIC to the lagoon facies of poorly cemented peloidal grainstone of Subunit IIIB-1. This interval (391393 mbsf, corresponds approximately to Core 144-878A-42M) is of late Aptian age. The upper portion of Subunit IIIC has patches and mottles of high resistivity, which may be differential cementation and/or algal enrichments in a wackestone-packstone facies. In contrast, Subunit IIIB-1 has a homogeneous low-resistivity material with a granular texture. Format of FMS image is explained in Figure 3.

biostratigraphic constraints on the lower carbonate platform and on the drowning of the upper platform (Shipboard Scientific Party, 1993; Grötsch and Flügel, 1992).

\section{Deepening Episode to Protected Lagoon with Storm-bed Intervals (196.7-147.4 mbsf; Logging Facies Subunits IIC-1 through IIC-5; middle Albian)}

The parasequence cyclicity was suddenly replaced by an extended interval of quiet-water lagoonal gastropod wackestone to packstone interbedded with sporadic concentrations of storm-redeposited or winnowed bioclastic debris. In contrast to the lagoonal deposits of lithologic Unit III, no significant deposits of homogeneous, peloid grainstone were observed in this facies. Variable relative abundances of ostracodes and benthic foraminifers in core recovery were interpreted as fluctuations from restricted to poorly oxygenated marine environments (Paleoecologic Assemblage II of Shipboard Scientific Party, 1993).

The lower $14 \mathrm{~m}$ consists of lime-mud-rich wackestone and packstone (Subunit IIC-1) with 1-m-scale alternations of resistivity that are interpreted as fluctuations in relative lime-mud content. The next $10 \mathrm{~m}$ appear to have an increased concentration of storm-winnowed 
or redeposited bioclasts (Subunits IIC-2 and IIC-3). Beds of coarse "rubble" in the FMS imagery are most significant in Subunit IIC-4 ( $6 \mathrm{~m}$ thickness). The core recovery within Subunit IIC-4 is a winnowed to reworked bioclastic grainstone with worn micritic intraclasts, large gastropods and mollusk shells, and oncolites (Ortonella type). This accumulation of storm-reworked material is overlain by 19 $\mathrm{m}$ of quiet-water wackestone-packstone with minor rubble-rich zones (Subunit IIC-5). This assemblage of quiet-water to storm-influenced protected lagoonal facies is assigned as a highstand systems tract, with a condensed transgressive deposit at the drowning of the underlying island surface.

\section{Storm-debris Accumulation and Emergence, Overlain by Algal-rich Facies (147.4-134.4 mbsf; Logging Facies Subunits IIC-6 and IIC-7, middle Albian)}

The lime-mud-rich lagoonal sediments are blanketed by a 7-mthick deposit of coarse rudstone with larger clasts (Subunit IIC-6). This deposit was observed only in the downhole logs and FMS imagery, where it forms a pronounced sharp-topped, very high-resistivity feature (Fig. 10). This rubble bed is similar to Subunit IIIA-7 and IIIA-8, and is interpreted as a storm-redeposited accumulation of carbonate platform and bioclastic debris forming an emergent shoal or small island. Enhanced cementation accompanied the emergent episode. This emergent rubble deposit may either represent a sea-level fall and associated sequence boundary or was a localized shoal deposit within the interior of the carbonate platform.

The overlying thin- to medium-bedded lime-mud-rich facies of wackestone-packstone has an increased uranium content associated with oncolites, cyanobacterial bushes (Ortonella) or other algal features (Subunit IIC-7, $4 \mathrm{~m}$ thickness; Fig. 11). The upper portion of this interval has a rubble-like texture in the FMS imagery, suggesting episodes of storm-bed accumulation. This interval is similar to a single upward-shallowing parasequence, such as observed in Subunit IID, but is immediately overlain by deeper water deposits. Therefore, it is a parasequence formed as part of a transgressive systems tract.

This set of facies of Subunits IIC-6 and IIC-7 is interpreted to represent a brief regression, lowstand, and initial transgression of relative sea level.

\section{Deepening Episode to Lagoon with Subdued Parasequences and Storm Beds (134.4-83.7 mbsf; Logging Facies Subunits IIC-8 through IIC-11; middle to late Albian)}

The next $20 \mathrm{~m}$ of peloid-rich wackestone to algal-rich packstonegrainstone and mollusk floatstone have subdued 5 -m-scale variations in resistivity (Subunit IIC-8). FMS imagery suggests that these variations may correspond to parasequences of algal-rich facies overlain by wave-winnowed grainstone. However, these variations and possible parasequences are more difficult to resolve in the downhole logs.

In contrast, the overlying 6-m interval displays two sharp-topped algal-rich parasequences (Subunit IIC-9). Algal-enrichment continues through the next $15 \mathrm{~m}$ of oncolite- (?Ortonella) and gastropodbearing wackestone and packstone (Subunit IIC-10) to peak in a $70-\mathrm{cm}$ layered deposit associated with a concentration of uranium (base of Subunit IIC-11). The overlying 10-m interval is also limemud-rich, but with a relatively minor algal contribution. Throughout this fine-grained and algal-bearing facies are coarse-debris layers, which are interpreted to be storm-reworking events.

This entire $50-\mathrm{m}$ interval is primarily a protected, moderate-depth, lagoon hosting a gastropod-algal biota and allowing accumulation of lime mud. Only sporadic storm-winnowing events affected this environment. Upward-shallowing parasequences generally have subdued expression. This succession represents an early highstand systems tract.

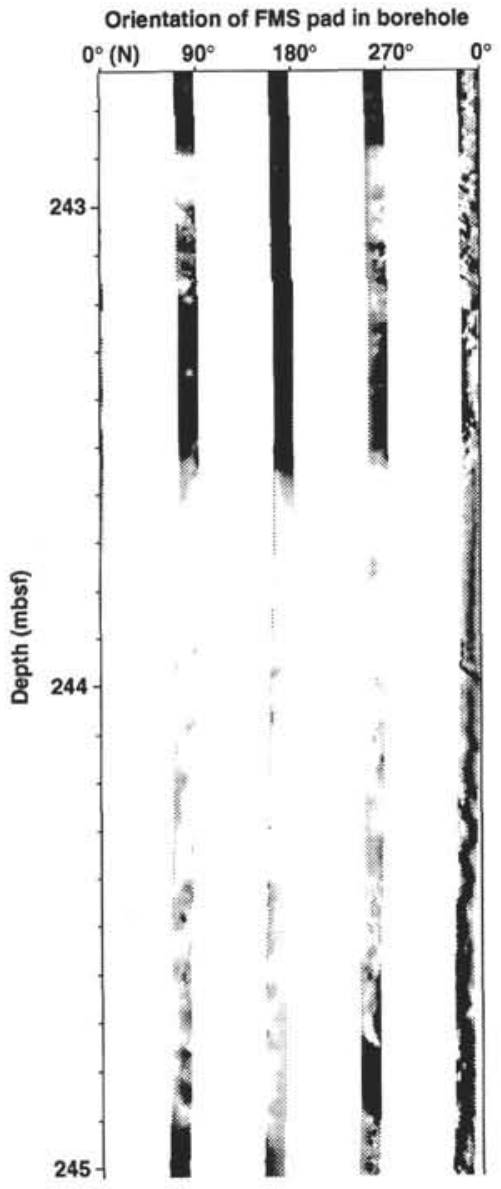

Figure 9. FMS static-processed image of a storm-debris shoal (Subunit IIIA-7) capped by a well-cemented layer of possible emergence (243.5-245.3 mbsf, Subunit IIIA-8). The upper surface of Subunit IIIA-8 is sharply overlain by the algal-rich facies of Subunit IID-1. This interval (243-245 mbsf, corresponding to lower Core 144-878 A-26M) is late Aptian or Albian in age. Subunits IIIA-7 and IIIA- 8 have a blocky appearance in dynamic-processed FMS imagery, and Subunit IIIA-8 has the highest resistivity of any interval within Hole 878A. This interval is interpreted as a storm-redeposited debris pile forming an emergent "island" shoal within the former lagoon. Format of FMS image is explained in Figure 3.

\section{Algal-rich and Peritidal Parasequences (83.7-55.4 mbsf; Logging Facies Subunits IIB-1 through IIB-4; middle to late Albian)}

The onset of well-developed shallow-water to intertidal parasequences was relatively sudden, as indicated at $83.7 \mathrm{mbsf}$. This rapid shallowing from the underlying moderate-depth lagoon facies could be interpreted as a sequence boundary.

Six to seven major parasequences were developed in an algal-rich facies with horizons of fenestral fabric and interbedded storm beds. The lower three parasequences (Subunit IIB-1, $8 \mathrm{~m}$ thickness) are relatively thin, which suggests deposition was superimposed upon a regressive trend in sea level. A lowstand in relative sea level was attained at the top of the fourth parasequence (Subunit IIB-2, 6 m thickness) containing fenestral-rich packstone and red-stained gastropod molds, perhaps associated with a brief emergence. The next three algal-rich parasequences (Subunits IIB-3 and IIB-4) average $5 \mathrm{~m}$ in thickness (Fig. 12).

These shallow-water to emergent parasequences were developed above an episode of rapid shallowing $(83.7 \mathrm{mbsf})$ and terminated by a deepening episode (55.4 mbsf). Therefore, this interval was deposited during a period of relative falling of eustatic sea level, hence may 
Figure 10. FMS static-processed and enhanced-contrast images of a stormdebris shoal (Subunit IIC-6) capped by a well-cemented layer with a surface of possible emergence at $138.6 \mathrm{mbsf}$. This interval (138-139.5 mbsf, corresponding approximately to Core 144-878A-15R; late Aptian or Albian in age) is similar to the upward-shallowing succession at the top of Subunit IIIA (Fig. 9). Subunit IIC-6 has a blocky appearance in the high-contrast FMS imagery (Fig. 11). This interval is interpreted as a storm-redeposited debris pile forming an emergent "island" shoal within the former lagoon. Format of FMS image is explained in Figure 3.

be equivalent to a "lowstand" systems tract on margins having slower rates of subsidence.

\section{Deepening Episode to Lagoon with Storm Beds, Followed by Upward-shallowing to Possible Emergence (55.4-30.0 mbsf; Logging Facies Subunits IIA-1 through IIA-3; late Albian?)}

The next cycle of deepening and shallowing begins with a tabular to lenticular "algal-layered" facies, typically associated with earlier algal-mat-rich environments (Subunit IIA-1, $11 \mathrm{~m}$ thickness). This algal-rich zone sharply overlies the upper surface of the peritidal parasequence of Subunit IIB-4. A general upward-increasing trend in resistivity punctuated by two thin storm beds may be a broadened parasequence in algal-mat facies superimposed on a long-term transgressive trend. In contrast to the parasequences in Subunit IIB, this upwardshallowing succession does not appear to attain peritidal depths. This is the highest interval observed in the FMS imagery with an abundance of algal structures, although oncolites and cyanobacterial nodules $(\mathrm{Or}$ tonella) are found to near the top of the carbonate platform.

A second deepening event terminates this algal-rich episode and forms a quiet-water lagoon with gastropod-bearing foraminifer wackestone (Subunit IIA-2, 5 m thickness). This early lagoon stage of limemud-rich sediment was protected from major storm waves.

The onset and progressive upward abundance of significant stormreworking and winnowed beds are interpreted as a shallowing of the lagoon (Subunit IIA-3, 9 m thickness). Gastropod-peloid wackestone to packstone with oncolites and cyanobacterial bushes (Ortonella) was recovered in this interval. Cementation (resistivity) and the abundance of "rubble" in the FMS imagery increase upward and peaks in a sharp-topped bed of very high resistivity. This uppermost bed is interpreted as a cementation horizon developed on an emergent shoal or island of storm-redeposited coarse debris.

The lower algal-mat-rich facies and lower quiet-water lagoon facies are considered to be a transgressive systems tract. The highstand systems tract is represented by the upward increase in storm influence, with a sequence boundary placed within the emergent shoal. The drowning of the debris island marks the onset of the next transgressive episode. Therefore, this $25 \mathrm{~m}$ succession represents a single depositional sequence.

\section{Storm-influenced Lagoon Terminating in a Submarine Hardground (30.0-3.2 mbsf; Logging Facies Subunits IIA-4 and IIA-5; late Albian)}

Overlying the well-cemented rubble-rich cap of the underlying sequence is another high-resistivity bed with a rubble-like texture in FMS imagery (Fig. 13), which is interpreted as storm-reworked debris onlapping the emergent surface. This was followed by a rapid

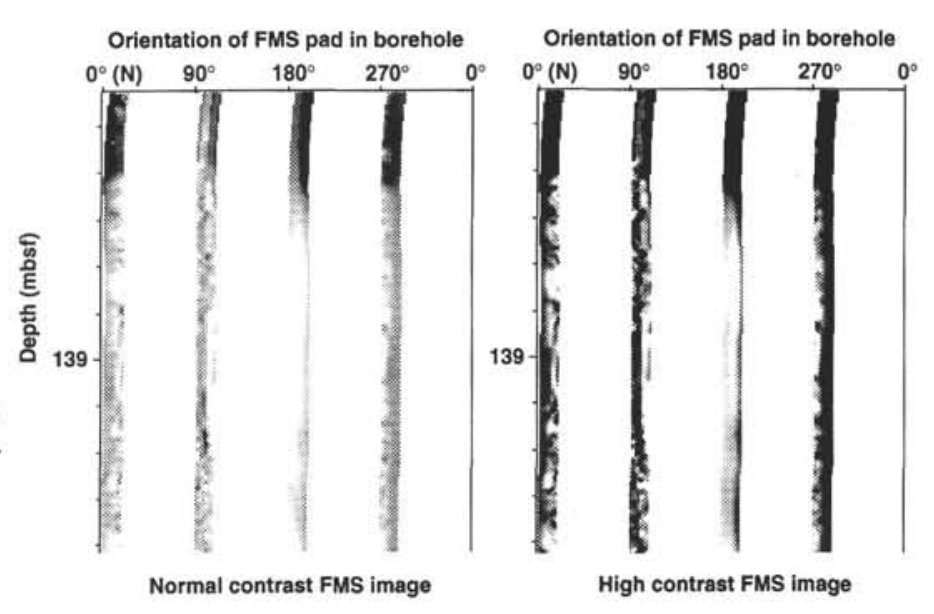

transition to a lagoonal facies of gastropod wackestone with variable amounts of lime mud, peloids, bivalves and oncolites (Ortonella) (Subunit IIA-4, 9 m thickness).

The uppermost sediments observed in the downhole logs of resistivity and the partially calibrated calcium geochemical log (Fig. 1) appear to be lagoon-type deposits with several episodes of storm reworking (Subunit IIA-5, approximately $22 \mathrm{~m}$ thickness). The highest FMS imagery (21 mbsf) shows a "rubble-textured" bed (Fig. 13) with a sharp base over a low-resistivity facies with a texture typical of wackestone-packstone. Alternations of well-cemented deposits of high resistivity, slow drilling rates, and associated high calcium content with less cemented beds appear to characterize the upper $25 \mathrm{~m}$ of the carbonate platform succession, and it is possible that the spacing and thickness of these deposits display a vague cyclicity.

The uppermost $2 \mathrm{~m}$ of the carbonate platform is a well-cemented bed, which is sharply overlain at approximately $3 \mathrm{mbsf}$ by low-porosity pelagic sediments. The associated core recovery indicates that gastropod wackestone-packstone continues to the top of the platform.

The combined evidence from the recovered facies, sustained low natural gamma-ray levels, and lack of a trend in the calcium log do not provide any indication of a late-stage upward-shallowing episode accompanied by algal-enrichment, as was characteristic of previous episodes of lagoon filling. Therefore, the uppermost cemented bed of the carbonate platform is probably submarine diagenesis, rather than a shallow-water sediment or storm-reworked accumulation. The highest recovered facies of wackestone also indicates quiet moderatedepth conditions at the top of the carbonate platform. The final stages of the carbonate platform that can be observed in the downhole logs in Hole 878 A appear to be a "lagoonal" facies with episodic wave or current redeposition and winnowing.

From this combination of logging observations, drilling rates and core recovery, it appears that the submergence of an emergent shoal of storm-deposited rubble was followed by a shallow- to moderatedepth storm-influenced "lagoonal" sedimentation, followed by further deepening into a moderate-depth lime-mud-rich "lagoon" depositional environment. Therefore, the final stages of the carbonate platform at this site appear to be a continuation of the "lagoonal" facies in moderate depths, but susceptible to wave- or current-induced redeposition and winnowing. This gastropod wackestone-packstone facies is capped by a manganese and phosphatic hardground. There are no indications of a terminal upward-shallowing and emergent episode in Hole 878 A.

Indeed, the effective drowning of the carbonate platform at Site 878 could be assigned to the submergence episode at the top of Subunit IIA-3 at $30.0 \mathrm{mbsf}$, and the overlying $27 \mathrm{~m}$ of "lagoon" deposits represent post-drowning sedimentation in moderate photiczone depths at rates inadequate to keep pace with continued submergence. In this model, the carbonate cap of MIT Guyot died, not with a bang, but with a whimper. 


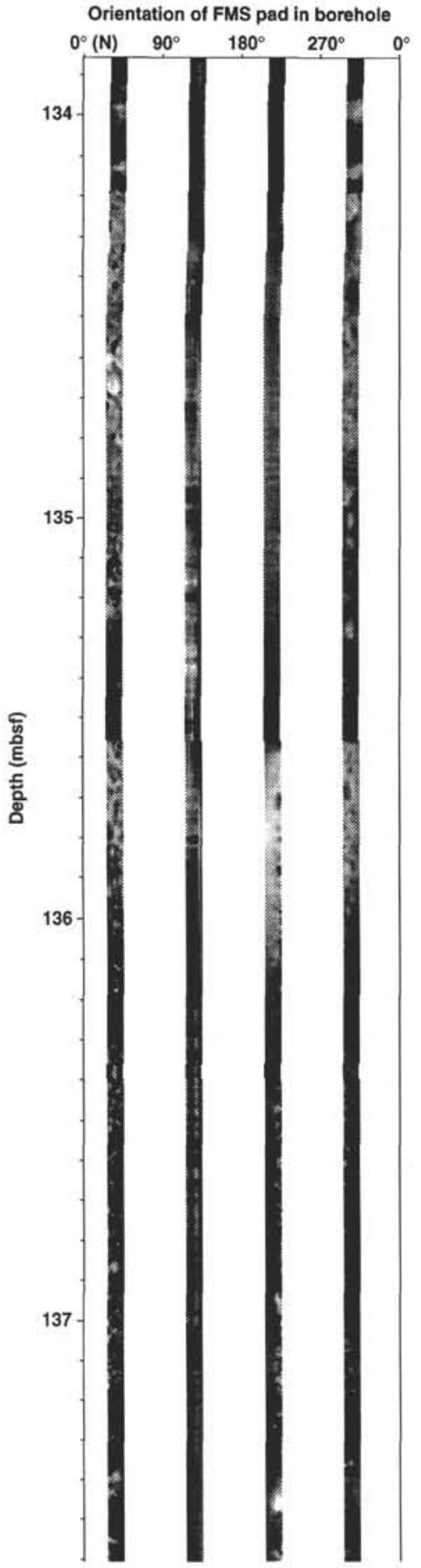

Figure 11. FMS static-processed image of an upward-shallowing cycle in an algal-rich facies (Subunit IIC-7). This interval (134-137 mbsf) corresponds approximately to Core 144-878A-15R of late Aptian or Albian age. Format of FMS image is explained in Figure 3.

\section{SUMMARY}

The Aptian-Albian platform succession at Site 878 was deposited in two stages, with a thick intervening volcanic breccia containing abundant xenolithic clasts of the earlier platform.

The lower carbonate platform of early to late Aptian age displays a series of lagoonal to algal-rich shallow-water facies.

The lower Aptian succession has an initial onlap of winnowed grainstone (Subunit VB-1) followed by an algal-rich facies with storm

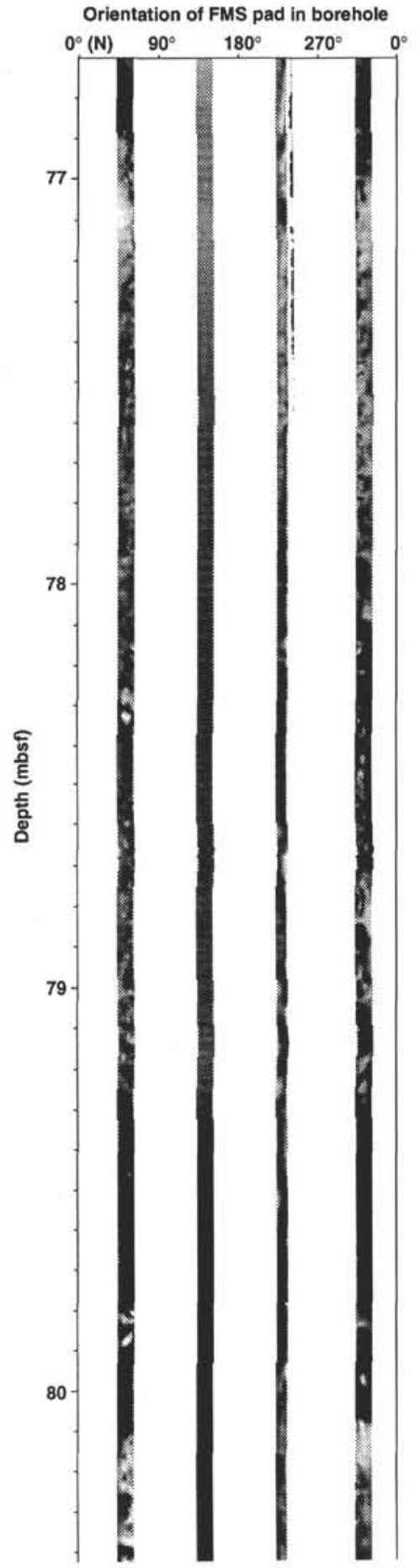

Figure 12. FMS static-processed image of a portion of an upward-shallowing parasequence in algal-rich, shallow-water facies (Subunit IIB-4). This interval (77-80 mbsf, corresponding to upper Core 144-878A-9R) is Albian in age. This interval has two medium- to high-resistivity beds with intervening lowresistivity facies; the uppermost high-resistivity bed has a sharp upper surface. Algal-layering texture is common in the high-resistivity beds, with "voids" (fenestrae?) and some "rubble" clasts. Fenestral vugs in recovered core pieces may indicate intertidal conditions during the "lowstand" upper portion of some cycles. Format of FMS image is explained in Figure 3. 


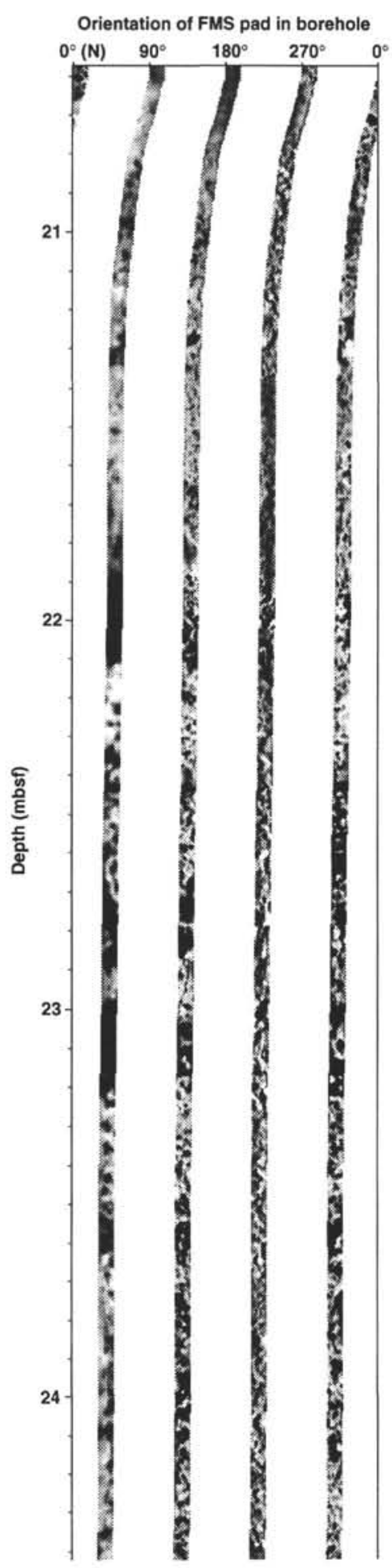

Fig. 13. FMS static-processed image of high-resistivity, storm-debris-rich Subunit IIA-4 near the top of the logged portion of Hole 878A. This interval (21-24 mbsf, corresponding approximately to Core 144-878A-3R; Albian in age) is similar to storm-redeposited shoals in other shallow-lagoon intervals (e.g., Fig. 10). In the dynamic-processed imagery, continuous contrast adjustment within a sliding window removes meter-scale trends but enhances smallscale textures. Format of FMS image is explained in Figure 3. beds (Subunit VB-2). A major deepening episode at $701 \mathrm{mbsf}$ formed a quiet-water lagoon (Subunits VA-1 and VA-2). A gradual upward shoaling of facies led to a shallow-water assemblage of winnowed grainstones, algal-coral-stromatoporoid horizons, peritidal sedimentary structures (Subunit VA-3), followed by a return to lagoonal or restricted environments (Subunits VA-4 and VA-5). Another brief shoaling episode is characterized by development of upward-shallowing parasequences (Subunit VA-6). A deepening episode at $623.5 \mathrm{mbsf}$ terminated the algal-rich facies, and the uppermost sediments of this first carbonate platform are poorly cemented grainstones with coated grains (Subunit VA-7 and VA-8).

The first carbonate platform was buried by two major explosive volcanic eruptions during the middle to late Aptian, which deposited nearly $200 \mathrm{~m}$ of mixed volcanic and limestone debris (Subunit IV). The debris pile underwent partial weathering and formation of a surface layer of organic-rich clay before being submerged ( $405 \mathrm{mbsf}$ ) in the late Aptian.

The upper carbonate platform of late Aptian to late Albian age exhibits a first phase of extended lagoonal conditions followed by a second phase characterized by four major upward-shallowing cycles. The biostratigraphy of this succession is inadequate to allow correlation to established eustatic sea level cycles.

A basal winnowed carbonate sand was followed by continued deepening into a quiet water lagoon with wackestone (Subunit IIIC) and homogeneous peloid grainstone (Subunit IIIB). Sponge-algal assemblages (Subunit IIIA-1) and beds of abundant bivalves and possible rudists (Subunit IIIA-2) are in the overlying peloid-foraminifer grainstone-packstone (Subunits IIIA-2 and IIIA-4). A general shallowing trend is recognized by an increasing abundance of bioclastic rudstone and storm-reworked deposits (Subunits IIIA-5 through IIIA-7), culminating in an emergent island of storm-deposited rudstone (Subunit IIIA-8).

The middle Albian submergence of this island ( $243.5 \mathrm{mbsf}$ ) was followed by a series of 12 major parasequences of gastropod-peloid wackestones shallowing to algal-rich grainstone (Subunit IID). A major deepening episode (197 mbsf) produced a lime-mud-rich lagoon facies with intervals of winnowed or reworked bioclastic grainstone (Subunits IIC-1 to IIC-5). An upward-shallowing trend ended with an emergent accumulation of bioclastic debris (Subunit IIC-6), overlain by a series of upward-shallowing algal-rich parasequences (Subunits IIC-7).

A third major cycle began with a moderate deepening episode (134 mbsf) to an algal-rich lagoon with storm beds (Subunits IIC-8 through IIC-11). This cycle was completed by a return to shallowwater to peritidal parasequences (Subunit IIB-1 through IIB-4).

The fourth cycle is relatively thin. An algal-rich facies (Subunit IIA-1) underwent deepening (44 mbsf) into a brief lagoon facies (Subunit IIA-2). A progressive upward increase in storm reworking peaked in an exposure surface on a shoal or island of coarse debris (Subunit IIA-3).

The final cycle began with a deepening ( $30 \mathrm{mbsf}$ ) into a storminfluenced lagoon (Subunits IIA-4 and IIA-5). Unlike in the earlier cycles, there is no evidence in the logs or recovered lithologies that this lagoon underwent another shoaling to an emergent horizon. The uppermost $2 \mathrm{~m}$ is a well-cemented bed, but the uppermost facies (approximately $3 \mathrm{mbsf}$ ) is a gastropod wackestone-packstone, typical of a "lagoonal" depositional environment. In Hole 878A, the drowning of the carbonate platform appears to have begun at $30 \mathrm{mbsf}$, and the uppermost $27 \mathrm{~m}$ of the carbonate platform succession is a "lagoon" facies with periodic current- and wave-reworking that was deposited as the guyot continued to deepen.

The present surface of the MIT Guyot summit plateau has an irregular bathymetry, with deep depressions up to $500 \mathrm{~m}$ in diameter and to $200 \mathrm{~m}$ below the summit level. Van Waasbergen and Winterer (1993) proposed that these depressions represent a karst topography formed by dissolution and other weathering processes during prolonged subaerial weathering of the exposed carbonate platform be- 
fore final drowning. The drilling results from Site 878 did not directly support a karst-solution phase during the final stage, but several intervals of probable exposure occurred at the culmination of the major upward-shallowing cycles. The repeated deepening and partial emergence of portions of the platform during the middle to late Albian may have contributed to this irregular topography.

\section{ACKNOWLEDGMENTS}

This research was partly sponsored by the Ocean Drilling Program and USSAC. Many of our interpretations of the depositional history are based upon the observations and presentations by our shipboard colleagues. Jürgen Grötsch provided preprints of his publications on drowning of Aptian-Albian carbonate platforms. Gabi Ogg drafted key figures and aided production of the manuscript versions. Valuable reviews and critiques were provided by Gilbert Camoin, Lubomir Jansa, Annie Arnaud-Vanneau, Ursula Röhl, and an anonymous reviewer.

\section{REFERENCES}

Asquith, G.D., 1979. Subsurface Carbonate Depositional Models: A Concise Review: Tulsa, OK (Petroleum Publ. Co.).

Bourke, L., Delfiner, P., Trouiller, J.-C., Fett, T., Grace, M., Luthi, S., Serra, O., and Standen, E., 1989. Using Formation MicroScanner images. Tech. Rev., 37:16-40.

Cooper, P., Amaud, H.M., and Flood, P.G., 1995. Formation MicroScanner logging responses to lithology in guyot carbonate platforms and their implications: Sites 865 and 866. In Winterer, E.L., Sager, W.W., Firth, J.V., and Sinton, J.M. (Eds.), Proc. ODP, Sci. Results, 143: College Station, TX (Ocean Drilling Program), 329-372.

Detrick, R.S., and Crough, S.T., 1978. Island subsidence, hot spots, and lithospheric thinning. J. Geophys. Res., 83:1236-1244.

Dorfman, M.H., Newey, J.-J., and Coates, G.R., 1990. New techniques in lithofacies determination and permeability prediction in carbonates using well logs. In Hurst, A., Lovell, M.A., and Morton, A.C. (Eds.), Geological Applications of Wireline Logs. Geol. Soc. Spec. Publ. London, 48:113-120.

Drummond, C.N., and Wilkinson, B.H., 1993a. Aperiodic accumulation of cyclic peritidal carbonate. Geology, 21:1023-1026.

1993b. On the use of cycle thickness diagrams as records of long-term sea-level change during accumulation of carbonate sequences. J. Geol., 101:687-702.

Ekstrom, M.P., Dahan, C.A., Chen, M.-Y., Lloyd, P.M., and Rossi, D.J., 1986. Formation imaging with microelectrical scanning arrays. Trans. SPWLA 27th Annu. Logging Symp., Pap. BB.

Goldhammer, R.K., Dunn, P.A., and Hardie, L.A., 1990. Depositional cycles, composite sea-level changes, cycle stacking patterns, and the hierarchy of stratigraphic forcing: examples from Alpine Triassic platform carbonates. Geol. Soc. Am. Bull., 102:535-562.

Goldhammer, R.K., Lehmann, P.J., and Dunn, P.A., 1993. The origin of high-frequency platform carbonate cycles and third-order sequences (Lower Ordovician El Passo Gp, west Texas): constraints from outcrop data and stratigraphic modeling. J. Sediment. Petrol., 63:318-359.

Gräfe, K.-U., and Wiedmann, J., 1993. Sequence stratigraphy in the Upper Cretaceous of the Basco-Cantabrian Basin (northern Spain). Geol. Rundsch., 82:327-361.

Grötsch, J., 1994. Guilds, cycles and episodic vertical aggradation of a reef (late Barremian to early Aptian, Dinaric carbonate platform, Slovenia). Spec. Publ. Int. Assoc. Sediment., 19:227-242.

Grötsch, J., and Flügel, E., 1992. Facies of sunken Early Cretaceous atoll reefs and their capping late Albian drowning succession (northwestern Pacific). Facies, 27:153-174

Harker, S.D., McGann, G.J., Bourke, L.T., and Adams, J.T., 1990. Methodology of Formation Micro Scanner image interpretation in Claymore and Scapa Fields (North Sea). In Hurst, A., Lovell, M.A., and Morton, A.C. (Eds.), Geological Applications of Wireline Logs. Geol. Soc. Spec. Publ. London, 48:11-25.

Jones, B., and Desrochers, A., 1992. Shallow platform carbonates. In Walker, R.G., and James, N.P. (Eds.), Facies Models: Response to Sea Level Change. Geol. Assoc. Can., 277-301.

Molinie, A.J., and Ogg, J.G., 1992a. Milankovitch cycles in Upper Jurassic and Lower Cretaceous radiolarites of the equatorial Pacific: spectral analysis and sedimentation rate curves. In Larson, R.L., Lancelot, Y., et al., Proc. ODP, Sci. Results, 129: College Station, TX (Ocean Drilling Program), 529-547. 1992b. Formation microscanner imagery of Lower Cretaceous and Jurassic sediments from the western Pacific (Site 801). In Larson, R.L., Lancelot, Y., et al., Proc. ODP, Sci. Results, 129: College Station, TX (Ocean Drilling Program), 671-691.

Osleger, D., 1991. Subtidal carbonate cycles: implications for allocyclic vs. autocyclic controls. Geology, 19:917-920.

Osleger, D., and Read, J.F., 1993. Comparative analysis of methods used to define eustatic variation in outcrop: late Cambrian interbasinal sequence development. Am. J. Sci., 293:157-216.

Pezard, P., and Luthi, S., 1988. Borehole electrical images in the basement of the Cajon Pass Scientific drillhole, California: fracture identification and tectonic implications. Geophys. Res. Lett., 15:1017-1020.

Pratt, B.R., James, N.P., and Cowan, C.A., 1992. Peritidal carbonates. In Walker, R.G., and James, N.P. (Eds.), Facies Models: Response to Sea Level Change. Geol. Assoc. Can., 303-322.

Premoli Silva, I., Haggerty, J., Rack, F., et al., 1993. Proc. ODP, Init. Repts., 144: College Station, TX (Ocean Drilling Program).

Serra, O., 1985. Shallow-water carbonate environment (Sect. 5.8). In Sedimentary Environments from Wireline Logs: Houston (Schlumberger Educ. Services), 143-154.

Shipboard Scientific Party, 1993. Site 878. In Premoli Silva, I., Haggerty, J., Rack, F., et al., Proc. ODP, Init. Repts., 144: College Station, TX (Ocean Drilling Program), $331-412$.

Tucker, M.E., and Wright, P.V., 1990. Carbonate Sedimentology: Oxford (Blackwell Sci. Publ.).

van Waasbergen, R.J., and Winterer, E.L., 1993. Summit geomorphology of Western Pacific guyots. In Pringle, M.S., Sager, W.W., Sliter, W.V., and Stein, S. (Eds.), The Mesozoic Pacific: Geology, Tectonics, and Volcanism. Geophys. Monogr., Am. Geophys. Union, 77:335-366.

Van Wagoner, J.C., Mitchum, R.M., Campion, K.M., and Rahmanian, V.D., 1990. Siliciclastic Sequence Stratigraphy in Well Logs, Cores, and Outcrops: Concepts for High-Resolution Correlation of Time and Facies. AAPG Methods in Stratigr. Ser., 7.

Wilson, J.L., 1975. Carbonate Facies in Geologic History: Berlin (SpringerVerlag).

Wilson, J.L., and Jordan, C., 1983. Middle shelf environments. In Scholle, P.A., Bebout, D.G., and Moore, C.H. (Eds.), Carbonate Depositional Environments. AAPG Mem., 297-343.

\footnotetext{
Abbreviations for names of organizations and publications in ODP reference lists follow the style given in Chemical Abstracts Service Source Index (published by American Chemical Society).
}

\section{Date of initial receipt: 4 February 1994 Date of acceptance: 15 September 1994 Ms 144SR-041}

\section{APPENDIX \\ Description and Interpretation of Facies Subunits}

The following summary of the carbonate facies integrates the independent observations from the cored sediments (typically much less than $1 \mathrm{~m}$ of recovery from each 10 -m cored interval), the quantitative resistivity measurements, the natural gamma-ray intensities, and the detailed FMS "textures" and vertical successions. Division of the lithologic succession into subunits is based initially upon the facies and nomenclature of shipboard-defined lithologic units. At Site 878, the two carbonate platform successions were denoted as lithologic Units V and III-II with lettered subunits. Additional subdivisions are defined according to coherent log-facies packets or individual recognized parasequences (Fig. 1). These subunits simplify later discussions of sedimentary history interpretation.

Relative FMS resistivity (darkness on gray-scale imagery) is expressed in a shorthand of "low" ( $<2 \Omega \mathrm{m})$, "medium" $(2-5 \Omega \mathrm{m})$, and "high" $(<5 \Omega \mathrm{m})$ resistivity. Relative resistivity of features produced in the dynamic-processed enhanced FMS imagery denoted as "higher" or "lower" resistivity, and do not imply fixed resistivity ranges. In the accompanying log-stratigraphy columns, the resistivity values from shallowly focused resistivity tool (SFLU instrument) are plotted after depth shifting to FMS depths. Some features on this resistivity $\log$ (resolution of $1 \mathrm{~m}$ ) have been adjusted by increasing or decreasing the sharpness and amplitude of peaks to agree with the high-resolution resistivity records of the FMS imagery (resolution of $2.5 \mathrm{~mm}$ ). 


\section{Lithologic Unit VI}

Basalt (727.5 mbsf to base of logs at $737.0 \mathrm{mbsf}, 10 \mathrm{~m}$ thickness)

Core 144-878A-79R (731.7 mbsf, $5.7 \mathrm{~m}$ recovery): basalt, with reddish purple clay-rich weathering surface; lower core has lithic tuff and basaltic breccia

Core 144-878A-78R (722.1-731.7 mbsf, 1.9 m recovery): basalt, overlain by skeletal grainstone; basalt-carbonate contact not recovered

\section{Summary of Logging Facies}

The resistivity log from 737 to 727.5 mbsf is characterized by two extremely high-resistivity layers at about $733.0-734.5$ and $727.5-729.0$ mbsf.

The lower layer has an apparent sharp lower contact to very low-resistivity lithology interpreted to be clay, and is overlain by a transition to low resistivity, which may be a weathering zone into another clay; these two clay intervals are the minimum in low-resistivity troughs below $700 \mathrm{mbsf}$.

The top of the upper layer has a narrow transition into a facies of lower resistivity. This is interpreted to be a weathering horizon that developed before the deposition of the overlying carbonate platform. The recovered core facies indicated that the uppermost basalt was pervasively altered. However, this clay-rich interval appears to be sharply truncated by the overlying carbonate platform facies, possibly indicating a wave-erosion episode before the preservation of carbonate sediments.

\section{Lithologic Subunit VB \\ Skeletal-Oolitic Grainstone, Coarse-Grained, with Minor Mollusk Coral Rudstone (700.9-727.5 mbsf, $26.6 \mathrm{~m}$ thickness, early Aptian)}

\section{Summary of Logging Facies}

This unit is characterized by medium-low resistivity with numerous concentrations of medium- to high-resistivity bands and tabular lenses. Natural gamma-ray intensity, recorded only in the upper portion, is of moderate intensity relative to the very low intensity of the overlying facies of Subunits VA-1 and VA-2. Subunit VB was subdivided into a grainstone-rich lower unit with possible subaerial exposure and an algal-rich upper unit with discrete storm beds (Fig. 3).

Interpretation: This facies is interpreted as an algal-rich environment with episodes of storm redeposition from oolitic shoals or offshore coral-rich banks. This initial phase of submergence was followed by further deepening and establishment of a restricted quiet lagoon (lower part of Subunit VA). The top of Subunit VB was placed at the termination of moderate-uranium concentrations, which are interpreted to be the termination of the algal-rich facies.

Logging Facies Subunit VB-1

(721.0-727.5 mbsf, $6.5 \mathrm{~m}$ thickness)

Core 144-878A-78R (722.1-731.7 mbsf, 1.9 m recovery): basalt, overlain by $40 \mathrm{~cm}$ of yellowish- 10 reddish-stained skeletal grainstone of peloids, red algal fragments including rhodoliths, few coral and bivalve fragments, and rare oolites

721.0-727.5 mbsf: Resistivity log (no FMS imagery) indicates undulatory medium- to low-resistivity facies with two high-resistivity beds ( 724.7 and $721.0 \mathrm{mbsf}$ ). The high-resistivity beds appear to be associated with uranium concentrations.

Interpretation: The base of the carbonate platform is a flooding surface, followed by a set of grainstone beds with a possible algal-rich facies. Reddish coloration and uranium peaks (redox concentrations?) suggest episodes of emergence. The parasequence was terminated by another deepening pulse.

Logging Facies Subunit VB-2

(700.9-721.0 mbsf, $20.1 \mathrm{~m}$ thickness)

Core 144-878A-77R (712.5-722.1 mbsf. $0.4 \mathrm{~m}$ recovery): oolitic grainstone, tan-colored, with coral fragments; one piece displays low-angle cross laminations. Elongated vugs parallel with bedding

Core 144-878A-76R (703.0-712.5 mbsf, $1.0 \mathrm{~m}$ recovery): grainstone of coated skeletal fragments; with intervals of bivalve-coral rudstone

709.3-721.0 mbsf: Dynamic FMS imagery shows thin discrete layers about $1 \mathrm{~m}$ apart within a more homogeneous lower resistivity matrix. A "blocky" or "rhodolith" texture at 711.5-714.0 mbsf is associated with a minor uranium-concentration on the natural gamma-ray log (Fig. 3).

700.9-709.3 mbsf: Lower $2 \mathrm{~m}$ is a medium-resistivity bed with a high-resistivity band (Fig. 3). A similar interbedded interval is at 703.2-704.6 mbsf. These alternate with intervals of a more granular-texture facies. The uppermost meter appears to contain some discrete blocks of high- or low-resistivity material. Uranium concentrations remain at a moderately high level.

Interpretation: The relatively high uranium concentration, coupled with FMS textures suggesting rhodolith or algal-encrustation facies (Fig. 3), indicate that Subunit VB-2 is algal-rich. However, the few recovered pieces appear to be preferentially from the more granular or blocky FMS-texture intervals of grainstone or rudstone, which probably represent storm-redeposited concentrations of bioclasts and coral rubble.

\section{Lithologic Subunit VA \\ Peloid Foraminifer Wackestone to Grainstone, with Intervals of Gastropod, Oyster, and Coral Rudstone (602.5-700.9 mbsf, $98.4 \mathrm{~m}$ thickness, early Aptian)}

\section{Summary of Logging Facies}

This interval has several distinct logging facies. A lower thin-bedded meter (Subunit VA-1) is followed by an interval of homogeneous low resistivity (Subunit VA-2). A return to moderate uranium concentrations is associated with abundant fluctuations in resistivity (Subunits VA-3 and VA-4). The resistivity fluctuations gradually develop a pronounced signature, which is associated with upward-shallowing parasequences (Subunits VA-5 and VA-6) (Fig. 4). A return to a more homogeneous low-resistivity unit with low uranium abundances (Subunit VA-7) was terminated by interbedded very low- and very high-resistivity beds with very high uranium concentrations (Subunit VA-8) (Fig. 5).

Interpretation: A deepening episode (Subunit VA-1) led to quiet lagoonal conditions (Subunit VA-2), followed by a progressive upward-shallowing trend to a restricted algal-rich environment (Subunits VA-3 to VA-4) and upward-shallowing parasequences (Subunits VA-5 and VA-6). Another deepening episode to lagoonal conditions (Subunit VA-7) was terminated by the early stages of a volcanic eruption of the volcanic pedestal (Subunit VA-8).

Logging Facies Subunit VA-1 (699.7-700.9 mbsf, $1.2 \mathrm{~m}$ thickness)

Core 144-878A-75R (693.5-703.0 mbsf, $1.5 \mathrm{~m}$ recovery): lower part of core has flaser structures in fine-grained packstone to mudstone; pelagic microfossils observed in the basal recovered sediments

699.7-700.9 mbsf: Thin-bedded alternations or elongate lenses of medium- to high-resistivity lithology. The FMS texture is different than within the underlying episodes of "algal-rich" high-resistivity facies dominated by thin lenses.

Interpretation: This subunit consists either of well-cemented mudstonewackestone beds associated with the onset of a deeper quiet-water environment or else of layers of algal encrustation. The low concentration of uranium and associated core lithology suggests the former alternative; therefore, a transgressive trend or maximum-flooding interval is proposed.

Logging Facies Subunit VA-2

(684.0-699.7 mbsf, $15.7 \mathrm{~m}$ thickness)

Core 144-878A-75R (693.5-703.0 mbsf, $1.5 \mathrm{~m}$ recovery): upper part of core is porous wackestone with thin mollusk fragments

Core 144-878A-74R (683.9-693.5 mbsf. 0.3 m recovery): nerineid-gastropod rudstone and peloidal packstone, and chalkified packstone; top piece is a coral colony fragment (downhole displaced?)

684.0-699.7 mbsf: Very low-resistivity facies, widened borehole, and low natural gamma-ray intensities. Dynamic FMS imagery displays a granular facies with thin beds of slightly higher resistivity at about $1-\mathrm{m}$ spacing. Upper $7 \mathrm{~m}$ has a coarser texture of either rudstone and/or partially cemented wackestone-packstone, in which uranium concentrations begin to increase.

Interpretation: This subunit is dominated by quiet- and deep-lagoonal facies of gastropod-bearing peloidal wackestone. The periodic beds of slightly higher resistivity may be episodes of storm winnowing, corresponding to the recovered gastropod concentrations, but no other indications of significant storm wave activity are present. The facies represents a highstand systems 
tract, with the beginning of an upward-shallowing trend commencing in the upper $7 \mathrm{~m}$.

Logging Facies Subunit VA-3

(663.0-684.0 mbsf, $21.0 \mathrm{~m}$ thickness)

Core 144-878A-73R (674.2-683.9 mbsf, $0.4 \mathrm{~m}$ recovery): coral-colony rudstone with grainstone matrix, and grainstone containing coral-mollusk fragments; calcisponges are also present

Core 144-878A-72R (664.6-674.2 mbsf, $0.2 \mathrm{~m}$ recovery): algal-stromatoporoid bindstone, fenestral wackestone, and ooid-peloid grainstone

663.0-684.0 mbsf: Patches and thin lenses of high resistivity in a mediumresistivity facies. Some intervals (e.g., 670.3-673.0 mbsf) have an increased concentration of these high-resistivity lenses. A moderate concentration of uranium is sustained through this unit. Dynamic FMS imagery has a texture similar to the algal-coral facies of Subunit VB-2.

Interpretation: Algal-coral "bioherm" patches are interbedded within winnowed lagoonal grainstones with contributions from oolite-pellet shoals. The general environment may have been similar to the Bahama lagoon of mixed algal-flats and oolite-shoals. No distinct upward-shallowing cycles or emergent episodes are apparent.

Logging Facies Subunit VA-4

(646.7-663.0 mbsf, $16.3 \mathrm{~m}$ thickness)

Core 144-878A-7IR (654.9-664.6 mbsf, $1.1 \mathrm{~m}$ recovery): skeletal grainstone of medium to very coarse rounded fragments of algae and bioclasts with low-angle cross laminae; overlain by coarse skeletal packstone with codiacean algae and calcisponges

Core 144-878A-70R (645.3-654.9 mbsf, 0.4 m recovery): peloid-skeletal wackestone-packstone, mollusk (gastropod-?rudist) wackestone, and stromatoporoid boundstone

646.7-663.0 mbsf: The FMS texture is similar to the underlying Subunit VA-3, but the concentrations of high-resistivity lenses are less pronounced. Uranium concentrations in natural gamma-ray intensity remain moderate, with intervals of lower concentration corresponding to intervals of few high-resistivity lenses.

Interpretation: A restricted shallow-lagoon facies of algal-stromatoporoid assemblages continued, but was possibly more protected from wave activity. The recovered lithologies from underlying Subunit VA-3 are grainstone-dominated, whereas Subunit VA-4 is more lime mud-rich.

Logging Facies Subunit VA-5

(628.3-646.7 mbsf, $18.4 \mathrm{~m}$ thickness)

Core 144-878A-69R (635.6-645.3 mbsf, $0.3 \mathrm{~m}$ recovery): peloid and miliolid foraminifer wackestone-packstone

Core 144-878A-68R (625.9-635.6 mbsf, 0.4 $\mathrm{m}$ recovery): miliolid foraminifer wackestone, overlain by nerineid gastropod rudstone with yellowstained foraminifer packstone matrix

628.3-646.7 mbsf: This unit has a relatively lower average resistivity than underlying and overlying units and lacks major concentrations of high-resistivity lenses. Dynamic FMS imagery has a patchy texture, suggesting either packstone-wackestone facies or "rubble" intervals. Uranium concentrations remain moderate. An interval of upward-increasing resistivity at $632.8-636.0$ mbsf has a sharp upper surface to a low-resistivity interval. The top of this subunit is placed at the base of a thin high-resistivity bed.

Interpretation: Quiet lagoon environment that is deeper than the underlying algal-flat-rich units. The upper portion of the unit has indications of upward-shallowing trends, which may represent the lowest episodes of the upward-shallowing cycles that characterize the overlying subunit.

$$
\text { Logging Facies Subunit VA-6 }
$$$$
\text { (623.5-628.3 mbsf, } 4.8 \mathrm{~m} \text { thickness) }
$$

Core 144-878A-67R (616.3-625.9 mbsf, $0.7 \mathrm{~m}$ recovery): peloid grainstone, algal-coated-grain bivalve rudstone (with oyster-like shells), red-algae and mollusk packstone with calcisponge, and gastropod packstone

623.5-628.3 mbsf: Set of three cycles of upward-increasing resistivity that are sharply terminated by the next low-resistivity base of the next cycle (Fig.
4). General FMS texture is similar to "algal" and grainstone facies of lower units. Basal layer of high resistivity at $628.3 \mathrm{mbsf}$ may be storm-winnowing event. The capping layer at $623.5 \mathrm{mbsf}$ has thin-bedded "algal flat" appearance.

Interpretation: This is a shallow and restricted lagoon to "algal flat" or grainstone shoal facies subject to storm winnowing. The upward-shallowing parasequences are the culmination of an upward-shallowing trend from the upper part of Subunit VA-5, but no evidence exists of emergent episodes. The thin width of the cycles (2-3 m), in contrast to the "usual" 4- to 5-m upwardshallowing cycles observed on other guyots drilled on Legs 143-144, suggests that eustatic sea levels were dropping during their formation.

Logging Facies Subunit VA-7 (606.1-623.5 mbsf, $17.4 \mathrm{~m}$ thickness)

Core 144-878A-66R (606.6-616.3 mbsf, $0.3 \mathrm{~m}$ recovery): grainstone of mollusk fragments, coated grains, and few ooids, with a large oyster shell and an orange-stained encrustation

606.1-623.5 mbsf: Low- to medium-resistivity interval with very low uranium concentrations. The FMS imagery has a granular texture, but with abundant 1- to 2-cm diameter spots or mottles of higher or lower resistivity (Fig. 4). High-resistivity "blocks" up to $30-\mathrm{cm}$ diameter are scattered within this unit. The layer at $622 \mathrm{mbsf}$ has a rubble-like appearance.

Interpretation: Grainstone to packstone with larger bioclasts or redeposited blocks. An open-marine lagoon environment of wave-winnowed sand with a few storm bed episodes and rare algal encrustations replaced the preceding algal-rich restricted lagoon.

Logging Facies Subunit VA-8

(602.5-606.1 mbsf, $3.6 \mathrm{~m}$ thickness)

Core 144-878A-65R (597.1-606.6 mbsf, $7.3 \mathrm{~m}$ recovery): basal few centimeters of core are peloid-oolite grainstone-packstone with intraclasts, bioturbation, and local limonite staining; overlain by breccia of vesicular basalt and limestone clasts

602.5-606.1 mbsf: This subunit of medium- to high-resistivity facies has a rubble-like appearance in the FMS imagery (Fig. 5). The upper portion of this zone has a rapidly increasing natural gamma-ray intensity. Two $10-\mathrm{cm}$, sharp-bounded beds of low resistivity interrupt the main facies, and are bounded by relatively high-resistivity "contact margins." The contacts dip toward $120^{\circ}$ (southeast), similar to paleomagnetically measured dip directions in the overlying volcanic-limestone breccia; however, these dips were not observed in the underlying carbonate platform succession.

Interpretation: The uppermost facies of the lower Aptian carbonate platform episode is storm-debris-rich (intraclast) oolite and peloid grainstone. The low-resistivity beds may be tuffs associated with the early phase of the following volcanic eruption. The local limonite staining may indicate an episode of emergence before the volcanic catastrophe or be caused by diagenetic mobilization of iron from the adjacent volcanic beds.

\section{Lithologic Subunit IVC \\ Volcanic Breccia with Alternating Carbonate-rich (Light) and Volcanic-rich (Dark) Intervals (513.2-602.5 mbsf, 89.3 m thickness, early to late Aptian)}

$$
\text { Summary of Logging Facies }
$$

The volcanic-limestone breccia facies, composed of steeply inclined beds with common slump and fluid escape structures and an upper portion enriched in volcanics, is characterized by very high natural gamma-ray intensity and very high resistivity. Trends of upward-increasing resistivity correspond to progressive enrichments in limestone with associated increases in cementation, whereas trends of upward-decreasing resistivity correspond to progressive enrichments in volcanic components. These different trends indicate different phases of the eruption and correspond to the seven subdivisions of Subunits IVC- 1 to IVC- 3 and IVB-1 to IVB-4.

Logging Facies Subunit IVC-1 (577.0-602.5 mbsf, $25.5 \mathrm{~m}$ thickness)

Core 144-878A-65R (597.1-606.6 mbsf, $7.3 \mathrm{~m}$ recovery): upper portions of core are volcanic-limestone breccia with an upward increase in the abundance of large limestone clasts 
Core 144-878A-64R (587.6-597.1 mbsf, $10.0 \mathrm{~m}$ recovery): volcanic-limestone breccia

Core 144-878A-63R (578.1-587.6 mbsf. $9.3 \mathrm{~m}$ recovery): volcanic-limestone breccia, carbonate-rich

577.0-602.5 mbsf: Resistivity begins very high, but continues to gradually increase upward to the highest values observed within Hole 878A. This trend is sharply terminated at $577.0 \mathrm{mbsf}$. The base of the subunit has a bed of very high resistivity, which may be an enhanced cementation at the facies contact to the underlying carbonate platform.

Interpretation: Recovered core lithologies indicate an upward increase in large limestone clasts and in the proportion of limestone and lime mud. This carbonate-rich episode probably represents the initial volcanic blast, excavating and enlarging a crater into the limestone platform.

Logging Facies Subunit IVC-2

(540.0-577.0 mbsf, $37.0 \mathrm{~m}$ thickness)

Core 144-878A-59R through $-62 R$ (540.1-578.1 mbsf, total of $34.8 \mathrm{~m}$ recovery): volcanic-limestone breccia with slanted banding by variable limestone and volcanic clast abundances

540.0-577.0 mbsf: Resistivity remains at a constant high level after an initial 12 -m-thick interval of relative decrease.

Interpretation: This eruptive phase is dominated by volcanic clasts. The bands dip primarily toward the southwest to southeast, which may indicate that this is a depositional slope from a main debris pile located to the northeast or northwest.

Logging Facies Subunit IVC-3

(513.2-540.0 mbsf, $26.8 \mathrm{~m}$ thickness)

Core 144-878A-56R through -58R (511.9-540.1 mbsf, total of $27.5 \mathrm{~m}$ recovery): volcanic-limestone breccia, with a decreasing-upward abundance of carbonate

513.2-540.0 mbsf: Progressive upward decrease in resistivity.

Interpretation: As the eruption became dominated by volcanic material, the relative amount of carbonate-debris decreased. The top of this subunit has an "eroded" contact to the overlying Subunit IVB.

Lithologic Subunit IVB

Volcanic Breccia with Highly Vesicular, Glassy Basalt and Limestone Clasts in a Predominantly Carbonate Matrix (405.4-513.2 mbsf, $107.8 \mathrm{~m}$ thickness, late Aptian)

Summary of Logging Facies

Subunit IVB represents a second eruptive phase, with an initial widening of the caldera throat contributing a new episode of carbonate-debris enrichment. There is an upward increase in abundance of volcanics. The top of the unit has ash tuff and is partly oxidized.

Logging Facies Subunit IVB-1

(461.0-513.2 mbsf, $52.2 \mathrm{~m}$ thickness)

Core 144-878A-5IR through -55R (464.4-511.9 mbsf, total of $35.7 \mathrm{~m}$ recovery): volcanic-limestone breccia, rich in carbonate component

461.0-513.2 mbsf: A basal horizon of very high resistivity is followed by a 7- to $8-\mathrm{m}$ interval of decreasing resistivity. The following $45 \mathrm{~m}$ displays a fairly constant resistivity with minor meter-scale fluctuations (Fig. 6).

Interpretation: As in the first phase, this second eruptive phase begins with a widening excavation into the former carbonate platform.

Logging Facies Subunit IVB-2

(417.0-461.0 mbsf, $44.0 \mathrm{~m}$ thickness)

Core 144-878A-46M through -50R (4I8.5-464.4 mbsf, total of $12.1 \mathrm{~m}$ recovery): volcanic-limestone breccia

418.5-464.4 mbsf: Progressive upward decrease from high toward medium resistivity. The general trend contains some minor small-scale reversals.

Interpretation: This trend represents the waning phase of the eruption. The vesicular or pumice texture of the volcanic clasts may contribute to the decrease in resistivity.
Logging Facies Subunit IVB-3

(407.1-417.0 mbsf, $9.9 \mathrm{~m}$ thickness)

Core 144-878A-45M (408.9-418.5 mbsf, $4.4 \mathrm{~m}$ recovery): volcanic-limestone breccia, reddish colored (in contrast to greenish color of the main breccia unit)

408.9-418.5 mbsf: This interval of medium resistivity has a lower resistivity relative to underlying phases of the volcanic breccia and a relatively lower uranium concentration.

Interpretation: Weathering alteration has penetrated into the volcanic breccia pile causing an oxidation depletion of uranium. This zone suggests a subaerial exposure; however, the overlying final eruptive phases of greenish ash were also preserved from erosive removal.

$$
\begin{aligned}
& \text { Logging Facies Subunit IVB-4 } \\
& \text { (405.4-407.1 mbsf, 1.7 m thickness) }
\end{aligned}
$$

Core 144-878A-44M (406.1-408.9 mbsf, $2.6 \mathrm{~m}$ recovery): upper $1.7 \mathrm{~m}$ is made up of three, green-colored, fine-grained volcanic breccia and tuff episodes of successively thinner and finer grained character, becoming clayrich at the top

405.4-407.1 mbsf: Each of three distinct sharp-topped beds within this low-resistivity interval are progressively thinner and of lower resistivity than the underlying one (Fig. 7).

Interpretation: The final eruptive phases were mainly volcanic ash.

$$
\begin{gathered}
\text { Lithologic Subunit IVA } \\
\text { Clay, Bluish Gray } \\
\text { (404.7-405.4 mbsf, 0.7 } \mathrm{m} \text { thickness, late Aptian) }
\end{gathered}
$$

Core 144-878A-43M (399.3-406.1 mbsf, $0.3 \mathrm{~m}$ recovery): basal $3 \mathrm{~cm}$ of core recovery is bluish gray clay with disseminated fine-grained pyrite and clasts of limestone

$$
\text { Summary of Logging Facies }
$$

A 70-cm-thick interval of very low resistivity (Fig. 7) and extremely high concentration of uranium marks this reducing-environment clay layer. The concentration of uranium was caused by redox scavenging. This subunit, which preceded the initial deposition of the overlying carbonate platform, was probably an intertidal marsh and/or estuary-like organic-rich mud deposit. The preweathering sediment was a volcanic tuff.

\section{Lithologic Subunit IIIC Foraminifer Wackestone and Mudstone (392.2-404.7 mbsf, 12.5 m thickness, late Aptian)}

Core 144-878A-43M (399.3-406.1 mbsf, $0.3 \mathrm{~m}$ recovery): upper portion of core is peloid packstone to mudstone, low porosity, with borings, ?rudist fragment, and bioclast grains

Core 144-878A-42M (389.8-399.3 mbsf, $0.2 \mathrm{~m}$ recovery): foraminiferostracod wackestone and mudstone, bioturbated, low porosity to lithographic texture, with local reddish staining

\section{Summary of Logging Facies}

This subunit is medium-resistivity facies with meter-thick alternations of slightly higher or lower relative resistivities. The lower portion has a granular texture (Fig. 7). The upper portion contains patches and mottles of high-resistivity, and is considered to be a mixed wackestone-packstone facies (Fig. 8). The overall texture in FMS imagery is similar to Subunit VA-5. The basal 50 $\mathrm{cm}$ is a homogeneous granular bed, and the overlying next $2 \mathrm{~m}$ have a higher uranium concentration than the overlying facies. The uppermost meter has a minor enrichment in uranium.

Subunit IIIC represents a quiet, lime-mud-rich lagoon. The initial carbonate bed was probably a storm- or wave-winnowed grainstone washed onto the underlying clay (Fig. 7), and the early shallow-water facies may have had some algal enrichment. This mud-rich facies is in sharp contrast to the overlying peloid sands (Fig. 8), which may indicate a change from an initial brackish to restricted lagoon environments to shallow lagoon with circulation sufficient to remove fine lime mud. 


\section{Lithologic Subunit IIIB \\ Peloid Grainstone, Friable, Fine to Medium Grained \\ (312.8-392.2 mbsf, $79.4 \mathrm{~m}$ thickness, late Aptian)}

Summary of Logging Facies

Subunit IIIB is a low-resistivity, low-uranium facies. An interval with sharp-topped cycles of upward-increasing resistivity (Subunit IIIB-2) separates two episodes of homogeneous granular facies (Subunits IIIB-1 and IIIB-3). Recovery was extremely low in the porous granular facies.

The peloid grainstone facies suggests a shallow lagoon in which the bottom was reworked by shrimp or other pellet producers.

Logging Facies Subunit IIIB-1

(356.0-392.2 mbsf, $36.2 \mathrm{~m}$ thickness)

Core 144-878A-41M (380.2-389.8 mbsf, $0.1 \mathrm{~m}$ recovery): peloid grainstone, white, fine-grained, with rare bivalve fragments

Core 144-878A-40M (370.5-380.2 mbsf, no recovery)

Core 144-878A-39M (360.9-370.5 mbsf, 0.4 recovery): peloid grainstone, white, medium to fine-grained with bivalve fragments and rare orbitolinids

356.0-392.2 mbsf: Very low resistivity facies with a granular texture in the dynamic FMS imagery (Fig. 8).

Interpretation: This lowest facies represents a lagoon with pelletized lime muds and no significant infauna. The sharp base to the underlying mud-rich Subunit IIIA is coincident with an incursion of planktonic foraminifers and nannofossils and may represent a sudden change in circulation conditions.

Logging Facies Subunit IIIB-2

(334.0-356.0 mbsf, $22.0 \mathrm{~m}$ thickness)

Core 144-878A-38M (351.2-360.9 mbsf, $0.2 \mathrm{~m}$ recovery): peloid grainstone with common bivalve fragments, porous

Core 144-878A-37M (341.6-351.2 mbsf, $0.3 \mathrm{~m}$ recovery): grainstone of foraminifers (orbitolinids), mollusk fragments; with a few worm tubes

Core 144-878A-36M (331.9-341.6 mbsf, $0.9 \mathrm{~m}$ recovery): grainstone to packstone of peloids and probable mollusk fragments; rare worm tubes

Subunit IIIB-2 contains four episodes displaying subtle trends of upwardincreasing resistivity, each terminated by the low-resistivity base of the succeeding cycle.

348.0-356.0 mbsf: Progressive upward increase in resistivity. The basal meter has four thin alternations of high- and low-resistivity lithologies, and apparently corresponds to an increased uranium content. Therefore, this basal meter may be an algal-rich zone. The uppermost meter of this cycle displays a style of bedding suggestive of algal encrustations, terminating in a rapid transition to the next cycle.

342.4-348.0 mbsf: A low resistivity, lower $2.7 \mathrm{~m}$ interval is followed by a rapid increase to medium resistivity.

338.3-342.4 mbsf: Above a sharp basal contact are $2.4 \mathrm{~m}$ of bedded low-resistivity facies overlain by a medium-resistivity facies. Sharp top.

336.7-338.3 mbsf: This cycle has a sharp top and base, but lacks the range of resistivity displayed by the underlying cycles.

334.0-336.7 mbsf: This interval of sustained medium-resistivity has an upper transition to the low-resistivity facies of Subunit IIIB-3.

Interpretation: These cycles are probably upward-shallowing parasequences developed in moderate depths within a lagoon or platform interior. The increased abundance of foraminifers and macrofossils suggests episodes of less restricted salinity. Subunit IIIB-2 probably represents a relatively more shallow episode, with possibly higher wave energy.

Logging Facies Subunit IIIB-3

(312.8-334.0 mbsf, $21.2 \mathrm{~m}$ thickness)

Core 144-878A-35M (322.2-331.9 mbsf, 0.1 m recovery): grainstone, fine grained with mainly unidentifiable grains and a few mollusk fragments

Core 144-878A-34M (312.6-322.2 mbsf, 0.3 m recovery): grainstone, fine grained with mainly unidentifiable grains and a few mollusk fragments

312.8-334.0 mbsf: Homogeneous, granular low-resistivity facies, with no significant features in the FMS imagery or natural gamma-ray logs.

Interpretation: This subunit represents a restricted lagoon or protected shelf environment dominated by pelletized muds.

\author{
Lithologic Subunit IIIA \\ Grainstone, Friable, Fine to Medium Grained, with Intervals \\ of Skeletal Rudstone Containing Rudist, Coral, \\ and Calcisponge Fragments \\ (243.5-312.8 mbsf, 69.3 m thickness, late Aptian or Albian)
}

Summary of Logging Facies

Subunit IIIA comprises a suite of distinct units representing episodes of bioclastic banks or algal-flat development within a lagoon. The base of the subunit was placed at the base of a high-resistivity suite of beds interpreted as a sponge-algal mound (Subunit IIIA-1), overlain by lagoonal peloid-foraminifer grainstones (Subunits IIIA-2 and IIIA-4), with a 2-m rudist-rich bank (Subunit IIIA-3). The upper portion of Subunit IIIA has increasing abundances of storm rubble from rudist-coral-algal bioherms (Subunits IIIA-5 and IIIA-7) with an intervening episode of algal mat development (Subunit IIIA-6). The subunit ends in a 2-m layer of very high resistivity (Subunit IIIA-8) that may be an episode of emergence (Fig. 9). In general, Subunit IIIA represents a highstand systems tract as the lagoon shallowed into the following parasequence-dominated Subunit IID.

Logging Facies Subunit IIIA-1 (306.8-312.8 mbsf, $6.0 \mathrm{~m}$ thickness)

Core 144-878A-33M (302.9-312.6 mbsf, 0.2 m recovery): grainstone with algal rhodoliths and encrusting calcisponges

306.8-312.8 mbsf: This interval has medium resistivity with thin laminae, tabular lenses and centimeter-scale balls of high resistivity. The general appearance in the FMS imagery is similar to other algal-rich intervals, but the natural gamma-ray intensity remains low. The upper contact is sharp.

Interpretation: The FMS imagery and recovered core lithology indicate development of a local algal-sponge bioherm. The lack of uranium enrichment suggests continued oxidized depositional conditions, presumably indicating active water circulation.

Logging Facies Subunit IIIA-2

(285.7-306.8 mbsf, $21.1 \mathrm{~m}$ thickness)

Core 144-878A-32M (293.4-302.9 mbsf, no recovery)

285.7-306.0 mbsf: This granular facies has primarily low to medium resistivity. Intervals of higher resistivity with an "algal" thin-bedded appearance in FMS imagery are at 299.0-300.5 and 293.0-293.7 mbsf. Moderate uranium concentrations are at $295-297 \mathrm{mbsf}$, and in the upper $2.5 \mathrm{~m}$ of the unit where resistivity gradually increases.

Interpretation: This unit is predominantly a lagoonal peloid-foraminifer grainstone with local concentrations of algae and/or macrofossils.

Logging Facies Subunit IIIA-3

(283.7-285.7 mbsf, $2.0 \mathrm{~m}$ thickness)

Core 144-878A-3IM (284.I-293.4 mbsf, $0.4 \mathrm{~m}$ recovery): peloid-foraminifer (orbitolinid) grainstone with abundant large bivalves (possibly rudists) and gastropods

416.7-421.9 mbsf: This interval has extremely high resistivity, especially at 283.5-285.0 mbsf, but a low uranium concentration. Contacts appear to dip toward $120^{\circ}$ (southeast).

Interpretation: This unusual bed was probably recovered in Core 144$878 \mathrm{~A}-31 \mathrm{M}$ because cores appear to preferentially recover the uppermost portion of the cored intervals. Therefore, it represents a bivalve or rudist "meadow." The upper surface may have been emergent, resulting in cementation of the upper (and unrecovered) portion.

$$
\begin{gathered}
\text { Logging Facies Subunit IIIA-4 } \\
\text { (274.6-283.7 mbsf, 9.1 m thickness) }
\end{gathered}
$$

Core 144-878A-30M (274.5-284.I mbsf, $0.4 \mathrm{~m}$ recovery): foraminifer grainstone, medium-grained and leached, with mollusk fragments and scattered larger benthic foraminifers

274.6-283.5 mbsf: This medium-resistivity interval with granular texture is similar to Subunit IIIA-2.

Interpretation: Lagoonal foraminifer-peloid grainstone. 
Logging Facies Subunit IIIA-5

(261.5-274.6 mbsf, 13.1 m thickness)

Core 144-878A-29M(264.9-274.5 mbsf, 0.1 m recovery): grainstone with abundant small foraminifers, rudist and gastropod fragments, and larger benthic foraminifers

261.5-274.6 mbsf: Series of thick (ca. $2 \mathrm{~m}$ ) beds with variable resistivity and homogeneous blocky internal texture. Some of these beds have sharp upper surfaces. Some intervals are granular, but other beds have a texture in dynamic FMS imagery of blocks of higher resistivity in a low-resistivity matrix. Uranium remains at low concentrations.

Interpretation: Rudstone of storm-redeposited and winnowed bioclastic debris. The $9 \mathrm{~cm}$ of core recovery is probably not representative of the dominant facies but of one of the grainstone intervals. This facies indicates a shallowing of the lagoon.

Logging Facies Subunit IIIA-6

(255.0-261.5 mbsf, $6.5 \mathrm{~m}$ thickness)

Core 144-878A-28M (255.2-264.9 mbsf, $0.1 \mathrm{~m}$ recovery): algal-peloid packstone and rudist rudstone

255.0-261.5 mbsf: This interval has medium resistivity with thin tabular lenses of high resistivity and has a moderate to high uranium concentration. The concentration of high-resistivity beds varies. The upper $2 \mathrm{~m}$ has a rubble-like texture, but is associated with the highest uranium concentrations.

Interpretation: This is an algae-rich facies with rudists, and was probably a subtidal algal flat environment.

Logging Facies Subunit IIIA-7

(245.3-255.0 mbsf, $9.7 \mathrm{~m}$ thickness)

Core 144-878A-27M (245.6-255.2 mbsf, no recovery)

245.3-255.0 mbsf: This high- to medium-resistivity interval (Fig. 9) displays a blocky appearance in the dynamic FMS imagery. The upper $2 \mathrm{~m}$ has fewer high-resistivity blocks. Uranium concentrations vary from high to moderate.

Interpretation: The facies is similar to Subunit IIIA-5 with storm-redeposited and winnowed bioclastic rudstone. This blocky facies continues into Subunit IIIA-8 where it is well cemented (Fig. 9), suggesting that the debris pile may have formed an emergent island.

Logging Facies Subunit IIIA-8

(243.5-245.3 mbsf, $1.8 \mathrm{~m}$ thickness)

Core 144-878A-26M (235.9-245.6 mbsf, 0.3 m recovery): lower portion of core is bivalve (rudist) rudstone to coarse foraminifer grainstone with red algae and orbitolinid foraminifers

243.5-245.3 mbsf: This bed has the highest resistivity of any interval in Hole 878 A and terminates in a sharp upper surface (Fig. 9). Uranium decreases in this interval, suggesting oxidation depletion. The dynamic FMS imagery indicates that the facies is similar to the underlying less-cemented Subunit IIIA-7.

Interpretation: An emergent surface on a shoal of bioclastic debris resulted in a subaerially cemented beachrock.

\section{Lithologic Subunit IID \\ Mudstone Coarsening Upward to Wackestone-packstone, with Gastropods and Medium Grainstone (196.7-243.5 mbsf, 46.8 $\mathrm{m}$ thickness, late Aptian or Albian)}

Summary of Logging Facies

Subunit IID is a suite of approximately 12 major cycles of upward-increasing resistivity. The individual facies successions or composite sets of cycles were designated as numbered subunits. Within each cycle, the FMS imagery and uranium concentrations indicate a variety of textures, ranging from algallayered to mottled (packstone-wackestone) to grainstone or rudstone. The middle of a cycle is commonly interrupted by a bed of slightly higher resistivity than the background facies; some of these appear to be sharp-bounded storm beds, others may be concentrations of algal laminations. These 3-to 4-m-thick cycles represent upward-shallowing parasequences in a gastropod-peloid wackestone to algal-rich grainstone facies, interpreted to be a sustained sea-level stillstand in a shallow-lagoonal setting. Detailed descriptions of each cycle will be omitted.

Logging Facies Subunit IID-1

(239.6-243.5 mbsf, $4.9 \mathrm{~m}$ thickness)

Core 144-878A-26M (235.9-245.6 mbsf, 0.3 m recovery): upper portion of core is foraminifer wackestone with pockets of peloid packstone

239.6-243.5 mbsf: This sharp-topped cycle of upward-increasing resistivity is algal-rich and has a sharp-top.

Logging Facies Subunit IID-2

(235.9-239.6 mbsf, $3.7 \mathrm{~m}$ thickness)

235.9-239.6 mbsf: The cycle has a basal meter of grainstone, followed by an algal-layered interval, and is capped by "rubble" bed with a transitional upper contact.

Logging Facies Subunit IID-3

(230.2-235.9 mbsf, 5.7 m thickness)

230.2-235.9 mbsf: This interval contains either two cycles or else a single cycle with a sharp-bounded higher resistivity storm bed in the center. The upper higher resistivity bed has an algal-layered appearance and a sharp top.

Logging Facies Subunit IID-4

(226.5-230.2 mbsf, $3.7 \mathrm{~m}$ thickness)

Core 144-878A-25M (226.3-235.9 mbsf, $0.03 \mathrm{~m}$ recovery): piece of mudstone with borings or worm tubes

226.5-230.2 mbsf: The upper half of this cycle appears to have algal-rich layers and ends with a rapid transition to next cycle.

Logging Facies Subunit IID-5

(223.3-226.5 mbsf, $3.2 \mathrm{~m}$ thickness)

223.3-226.5 mbsf: The sharp upper surface of the capping high-resistivity bed to this cycle may indicate a brief period of emergence.

Logging Facies Subunit IID-6

(219.2-223.3 mbsf, $4.1 \mathrm{~m}$ thickness)

Core 144-878A-24M (216.6-226.3 mbsf, $0.1 \mathrm{~m}$ recovery): peloid-rich wackestone with pellet-filled burrows, rare shell molds, and a few coated (red-algal encrusted?), 5-mm-diameter nodules

219.2-223.3 mbsf: The cycle has possible algal layers throughout and a transitional top.

Logging Facies Subunit IID-7

(212.3-219.2 mbsf, $6.9 \mathrm{~m}$ thickness)

212.3-219.2 mbsf: This may be two cycles with a sharp break at 215.4 mbsf. The upper portion has a rubble or mottled appearance and high uranium concentration.

Logging Facies Subunit IID-8

(209.2-212.3 mbsf, $3.1 \mathrm{~m}$ thickness)

Core 144-878A-23M (206.9-216.6 mbsf, $0.1 \mathrm{~m}$ recovery): peloid packstone with few gastropods, algal fragments, and miliolid foraminifers; pelletfilled burrows are also present; shells have possible red-algal encrustations

209.2-212.3 mbsf: This cycle has two medium-resistivity peaks within a low-resistivity background lithology.

Logging Facies Subunit IID-9

(204.7-209.2 mbsf, $3.5 \mathrm{~m}$ thickness)

204.7-209.2 mbsf: This compound suite of three sharp-bounded, mediumresistivity layers may represent storm beds that are superimposed on a lowamplitude cycle continuing into the next subunit. 
Logging Facies Subunit IID-10

(200.4-204.7 mbsf, $4.3 \mathrm{~m}$ thickness)

Core 144-878A-22M (202.2-206.9 mbsf, $0.1 \mathrm{~m}$ recovery): peloid grainstone, very porous

200.4-204.7 mbsf: A "rubble" or mottled (packstone-wackestone) is overlain by grainstone, then by an algal-layered facies with a sharp termination. The latter facies is associated with a higher uranium concentration.

Logging Facies Subunit IID-11

(196.7-200.4 mbsf, $3.7 \mathrm{~m}$ thickness)

Core 144-878A-21R (192.5-202.2 mbsf, $0.1 \mathrm{~m}$ recovery): mollusk wackestone with rare green and red algae fragments; one piece has a highly bored surface with some fillings by pelleted(?) lime mud

196.7-200.4 mbsf: A grainstone is overlain by rubble-texture facies with a sharp top. The recovered core lithology contains a bored surface, which may represent a storm scour into more cohesive mud.

\section{Lithologic Subunit IIC}

Skeletal Wackestone with Minor Packstone-grainstone and Rudstone, Oyster-rich in Lower Horizons and Gastropod-rich in Upper Horizons (83.7-196.7 mbsf, 113.0 m thickness, late Aptian or Albian)

\section{Summary of Logging Facies}

The lower portion of Subunit IIC is a low- to medium-resistivity, mottled to granular facies with two intervals containing abundant high-resistivity "clasts" (Subunits IIC-2 and IIC-4). The depositional environment is a quiet to restricted lagoon (gastropod wackestone to peloid packstone, with no major storm beds), alternating with episodes of storm-redeposited or winnowed bioclastic debris. The continued presence of gastropods and wackestone in the recovered cores indicates normal-salinity lagoon conditions, similar to the lower restricted-lagoon facies of Subunit IIIB.

The middle portion of Subunit IIC (Figs. 10 and 11) is a shallower setting of an emergent shoal or "island" of bioclastic debris (Subunit IIC-6) followed by an algal-rich, upward-shallowing parasequence (Subunit IIC-7). The upper portion of Subunit IIC is a return to a lime-mud-rich moderate-depth lagoonal facies with sporadic storm-redeposition, subdued parasequences and some oncolite-rich intervals (Subunits IIC-8 and IIC-10 to IIC-11). The middle of this protected-lagoon facies contains algal-rich parasequences (Subunit IIC-9).

In general, Subunit IIC represents a transgressive deepening, followed by a brief episode of shallowing (Subunits IIC-6 and IIC-7), then a return to deeper lagoon conditions (Subunits IIC-8 through IIC-11).

Logging Facies Subunit IIC-1

$$
\text { (182.5-196.7 mbsf, } 14.2 \mathrm{~m} \text { thickness) }
$$

Core 144-878A-20R (182.8-192.5 mbsf, $0.02 \mathrm{~m}$ recovery): piece of gastropod wackestone

182.8-192.5 mbsf: This interval has a generally low-medium resistivity, with $1-\mathrm{m}$-scale alternations of higher and lower resistivity. The dynamic FMS imagery shows scattered mottles or "clasts" of higher resistivity. The widened borehole prevents precise determination of facies characteristics.

Interpretation: This facies represents a quiet lagoon environment with possible local enrichments in bioclasts and with meter-scale variations in the proportions of packstone to wackestone.

Logging Facies Subunit IIC-2

(175.8-182.5 mbsf, $6.7 \mathrm{~m}$ thickness)

Core 144-878A-19R(173.1-182.8 mbsf, 0.1 m recovery): wackestone with gastropod molds, oyster valve, and filled burrows

175.8-182.5 mbsf: This medium-resistivity interval has sharp contacts to adjacent low-resistivity "lagoon" subunits. The dynamic FMS imagery has a "rubble" appearance and suggests internal subdivision into a suite of beds.

Interpretation: The lagoon facies has an increased concentration of storm-winnowed or redeposited bioclasts relative to the underlying unit. Alternatively, this interval may represent only a change in the relative average lime-mud content of the lagoonal wackestone-packstone facies.
Logging Facies Subunit IIC-3

(172.2-175.8 mbsf, $3.6 \mathrm{~m}$ thickness)

172.2-175.8 mbsf: This unit has low-resistivity, but the texture is similar to the mottled or "rubble" appearance of adjacent higher resistivity units.

Interpretation: This facies is a lagoonal environment with storm winnowing, but is less cemented than adjacent units.

Logging Facies Subunit IIC-4

(166.7-172.2 mbsf, $5.5 \mathrm{~m}$ thickness)

Core 144-878A-18R (163.4-173.1 mbsf, 0.3 m recovery): grainstone with large bioclasts of gastropods, oncolites (Ortonella type), mollusk shells, and worn micritic intraclasts; overlain by oyster to gastropod wackestone with sponge spicules

163.4-173.1 mbsf: In dynamic FMS imagery, this set of high-resistivity beds with sharp internal bedding has a "rubble" appearance similar to Subunit IIC-2.

Interpretation: These beds are a set of storm-redeposited or winnowed concentrations of bioclasts. The recovered facies included "worn micritic intraclasts," which suggests storm scouring of former lagoonal wackestone deposits.

Logging Facies Subunit IIC-5

(147.4-166.7 mbsf, $19.3 \mathrm{~m}$ thickness)

Core 144-878A-17R (153.7-163.4 mbsf, no recovery)

Core 144-878A-16R (144.0-153.7 mbsf, 0.1 m recovery): skeletal peloid packstone with gastropods, minor bivalves, algae and sponge laminae, and a piece of bored oyster shell

147.4-166.7 mbsf: This interval of generally low to medium resistivity coincides with a widened borehole. Dynamic FMS imagery indicates some "rubble-rich" intervals, similar to Subunit IIC-2, but with a lower density of "clasts"; some of these may also be differential cementation of a mixed wackestone-packstone facies.

Interpretation: The quiet lagoon facies may possibly have bioclast-rich beds caused by storm winnowing.

Logging Facies Subunit IIC-6

(138.6-147.4 mbsf, $6.8 \mathrm{~m}$ thickness)

138.6-147.4 mbsf: Above a sharp lower contact, a progressive increase in resistivity ends sharply in a very high-resistivity peak (Fig. 10). The dynamic FMS imagery has a coarse rubble-like texture (Fig. 10), unlike the more granular texture of the underlying unit, and with larger "clasts" than the debris concentrations of Subunit IIC-4.

Interpretation: An emergent shoal or island was formed by a concentration of carbonate platform and bioclastic debris. This facies was apparently not recovered during coring. This episode is either a lowstand deposit, or a localized storm-debris accumulation within the lagoon.

$$
\begin{gathered}
\text { Logging Facies Subunit IIC-7 } \\
\text { (134.4-138.6 mbsf, } 4.2 \mathrm{~m} \text { thickness) }
\end{gathered}
$$

Core 144-878A-15R (134.4-144.0 mbsf, $0.2 \mathrm{~m}$ recovery): wackestonepackstone, possibly peloidal, with gastropod molds, oncolites or cyanobacterial bushes (Ortonella), and leached sponge spicules; chalky

134.4-138.6 mbsf: An increase in uranium concentration is associated with thin- to medium-bedded facies that is "algal-layered" in lower portion and "rubble-like" in upper portion (Fig. 11).

Interpretation: This interval is interpreted to be a single upward-shallowing parasequence developed after drowning of the underlying surface. An algal-rich facies is followed by increased accumulation of storm debris. The parasequences of the overlying Subunit IIC- 8 are more muted as a result of continued deepening of the depositional environment.

Logging Facies Subunit IIC-8

(114.9-134.4 mbsf, $19.5 \mathrm{~m}$ thickness)

Core 144-878A-14R (124.8-134.4 mbsf, $0.1 \mathrm{~m}$ recovery): peloid wackestone with rare foraminifers, bioturbated and chalkified

Core 144-878A-13R (115.1-124.8 mbsf, $0.2 \mathrm{~m}$ recovery): packstone. grainstone with abundant algae and some foraminifers, laminated; and mollusk-gastropod floatstone with packstone-wackestone matrix 
114.9-134.4 mbsf: This interval has subdued 5-m-scale variations between low-and medium-resistivity. The facies of these low-amplitude cycles vary from possible algal-layered (with associated increased uranium concentrations) to "rubble"-rich to granular. Some of these alternations have sharp upper surfaces and vaguely resemble parasequences. Algal-layered intervals are especially apparent in the basal meter, at 129.7, 124.0, and from 118 to $115 \mathrm{mbsf}$.

Interpretation: The limited core recovery supports the interpretation of variable bioclast concentrations (floatstone to rudstone) within a general lagoonal facies. There may be an upward-shallowing trend within the upper few meters of this subunit.

$$
\begin{aligned}
& \text { Logging Facies Subunit IIC-9 } \\
& \text { (109.3-114.9 mbsf, } 5.6 \mathrm{~m} \text { thickness) }
\end{aligned}
$$

Core 144-878A-12R (105.5-115.1 mbsf, $0.2 \mathrm{~m}$ recovery): packstone to grainstone with unrecognizable grains; and gastropod-mollusk wackestone to lime-mud-rich rudstone

111.2-114.9 mbsf: A progressive upward increase in resistivity ends in sharp upper surface. The lower portion is associated with increased uranium concentration.

109.3-111.2 mbsf: This thin cycle of upward-increasing resistivity has algal layering in the upper portion and a sharp upper surface.

Interpretation: These are two upward-shallowing algal-rich parasequences.

Logging Facies Subunit IIC-10

(94.7-109.3 mbsf, $14.6 \mathrm{~m}$ thickness)

Core 144-878A-IIR (95.9-105.5 mbsf, 0.03 m recovery): piece of oncolite (?Ortonella) wackestone-packstone with gastropods

94.7-109.3 mbsf: This low-resistivity interval has beds of medium resistivity. The dynamic FMS imagery indicates a general homogeneous to mottled texture with "cavities" of low- to no-resistivity material. There are sporadic layers, 20- to 40-cm thick, of minor concentrations of "rubble," but otherwise the depositional environment seems to be "quiet." One thicker and coarser "debris" bed is at $98.5-100.3$ mbsf.

Interpretation: This represents a protected lagoon with a lime-mud facies containing oncolites and occasional storm winnowing events. Parasequences, if present, are subdued. The depositional environment appears to be deeper than in Subunit IIC-9.

Logging Facies Subunit IIC-11

(83.7-94.7 mbsf, $11.0 \mathrm{~m}$ thickness)

Core 144-878A-10R (86.2-95.9 mbsf, 0.15 m recovery): peloid wackestone with oncoids, and bivalve and gastropod fragments

86.2-95.9 mbsf: Subunit IIB-3 is distinguished by a lower average uranium than underlying Subunit IIB-2; otherwise it has a similar appearance with mottled to "rubble" texture in the FMS imagery. The basal $70 \mathrm{~cm}$ has algal layering.

Interpretation: Quiet lagoon with reduced algal content.

Lithologic Subunit IIB

Peloid Packstone with Fenestral Fabric, Peloid-algal Wackestone, and Minor Grainstone

(55.4-83.7 mbsf, $28.3 \mathrm{~m}$ thickness, Albian)

\section{Summary of Logging Facies}

Subunit IIB is characterized by cyclic changes in resistivity and variable uranium concentrations. These are generally organized in cycles of progressively increasing resistivity (Fig. 12), which are interpreted to be upward-shallowing parasequences and were used to define the different logging subunits (IIB-1 through IIB-4). The recovered facies include algal-rich layers to algalmat intervals, "debris" beds from probable storm events, gastropod wackestone, and packstone with fenestrae. The high-amplitude parasequences are interpreted as relatively shallow to peritidal depositional environments. The top of Subunit IIB was placed at the change to the deeper water, mudstone-rich facies of the lower portion of lithologic Subunit IIA. This boundary is at a higher depth than the shipboard assignment, which had been based on the limited recovery.
Logging Facies Subunit IIB-1

(75.7-83.7 mbsf, $8.0 \mathrm{~m}$ thickness)

Core 144-878A-9R (76.6-86.2 mbsf, $0.2 \mathrm{~m}$ recovery): mollusk-peloid wackestone-packstone with algae, and abundant fenestral porosity; overlain by peloid-algal wackestone

75.7-83.7 mbsf: These three medium- to high-resistivity beds are interbedded with a low-resistivity facies; the uppermost high-resistivity bed has a sharp upper surface (Fig. 12). The FMS imagery is dominated by an algal-layering texture with "voids" (fenestrae?) and some "rubble" clasts.

Interpretation: Parasequences in an algal-flat facies. Fenestrae in recovered core pieces may indicate intertidal conditions during the "lowstand" upper portion of some cycles.

Logging Facies Subunit IIB-2

(69.9-75.7 mbsf, $5.8 \mathrm{~m}$ thickness)

Core 144-878A-8R (67.0-76.6 mbsf, $0.3 \mathrm{~m}$ recovery): peloid grainstone and fenestral-rich packstone with possible algal layering; overlain by gastropod wackestone with red stains in molds

69.9-75.7 mbsf: This major upward-increasing resistivity trend has a sharp upper termination. Secondary internal peaks of resistivity may be stormconcentrations of debris.

Interpretation: This upward-shallowing parasequence is dominated by algal-flat facies. Fenestrae suggest intertidal conditions during portions of the cycle. This parasequence probably represents the shallowest water depths within Subunit IIB.

Logging Facies Subunit IIB-3

(64.9-69.9 mbsf, $5.0 \mathrm{~m}$ thickness)

64.9-69.9 mbsf: This cycle is similar to the underlying Subunit IIB-5 cycle, but has a narrower capping peak of lower resistivity and contains several beds of higher resistivity.

Interpretation: This parasequence of algal-flat facies contains several storm beds.

Logging Facies Subunit IIB-4

(55.4-64.9 mbsf, $9.5 \mathrm{~m}$ thickness)

Core 144-878A-7R (57.3-67.0 mbsf, $0.3 \mathrm{~m}$ recovery): algal- or cyanobacterial-rich (Ortonella) wackestone with coated grains and bioturbation mottling

Core 144-878A-6R (47.6-57.3 mbsf, $0.2 \mathrm{~m}$ recovery): mollusk-gastropodforaminifer wackestone with algal concretions (Ortonella), and micritic algal crust and storm-scour surface on one piece

55.4-64.9 mbsf: This interval has an overall upward increase in resistivity ending in a sharp upper surface. High uranium concentrations are in the basal $3 \mathrm{~m}$ and uppermost meter; the interval from 61.0-64.5 mbsf has an "oncolite" aspect in FMS imagery. This cycle may be a composite of two parasequences with an intermediate surface at $59.1 \mathrm{mbsf}$.

Interpretation: This interval consists of one or two parasequences developed in an algal-flat facies.

Lithologic Subunit IIA

Wackestone and Peloid Packstone with Molds and Recrystallized

Fragments of Nerineid Gastropods Abundant in the Upper Half (3.2-55.4 mbsf, $52.2 \mathrm{~m}$ thickness, Albian)

Summary of Logging Facies

Subunit IIA was logged only up to $17 \mathrm{mbsf}$. The lower portion has low average resistivity, in contrast to the upper portion, which consists of a series of high-resistivity beds. The lower portion contains significant algal-mat structures (Subunits IIA-1) followed by further deepening into a quiet-water lime-mud-rich lagoon facies (Subunit IIA-2). This lagoon rapidly shallows through a storm-influenced stage (Subunit IIA-3) capped by a possible exposure surface.

The upper logged portion of Subunit II appears to consist of mixed algalmat and lime-mud-rich lagoonal facies with local abundances of debris (Sub- 
units IIA-4 and IIA-5) (Fig. 13). The highest logged interval of Hole 878A indicates an upward-shallowing event, followed by a lagoonal facies, but consisting of well-cemented beds with a storm-debris character (Fig. 13). The increased resistivity (cementation) may be an artifact of later exposure or submarine cementation, rather than indicative of the original depositional conditions.

Logging Facies Subunit IIA-1

(44.5-55.4 mbsf, $10.9 \mathrm{~m}$ thickness)

44.5-55.4 mbsf: This is a subdued cycle of upward-increasing resistivity with secondary beds of higher resistivity at 50.9 and $48.1 \mathrm{mbsf}$. The FMS imagery suggests a continuation of the tabular lenticular "algal-layered" facies throughout the upper portion of relatively high resistivity. The cycle is capped by a rapid upward transition to a low-resistivity facies.

Interpretation: The base of this unit represents a deepening episode that terminates the peritidal parasequences of Subunit IIB. Subunit IIA-1 is the highest interval containing an abundance of algal-mat-type sedimentary structures observed directly in the FMS imagery of Hole 878A, although oncolites (Ortonella) also occur as high as Core 144-878A-3R. A second deepening event terminated this algal-rich episode.

\section{Logging Facies Subunit IIA-2 \\ (39.0-44.5 mbsf, $5.5 \mathrm{~m}$ thickness)}

Core 144-878A-5R (38.0-47.6 mbsf, $0.1 \mathrm{~m}$ recovery): foraminifer wackestone with gastropods, bioturbated

39.0-44.5 mbsf: Low resistivity, a widened borehole, and low uranium levels characterize this interval. The FMS imagery indicates a mottled to "rubble" appearance, probably as a result of differential cementation of a wackestone-packstone.

Interpretation: This is a quiet lagoonal environment without significant storm reworking.

Logging Facies Subunit IIA-3

(30.0-39.0 mbsf, $9.0 \mathrm{~m}$ thickness)

30.0-39.0 mbsf: An upward increase in resistivity corresponds to increasing abundance of higher resistivity "rubble" in the FMS imagery. This is capped by a very high resistivity bed with a sharp upper surface.

Interpretation: The lagoonal deposits have an increasing abundance of storm-reworked or winnowed beds. The uppermost surface may represent an emergent shoal of storm debris ("island").

Logging Facies Subunit IIA-4

(25.6-30.0 mbsf, $4.4 \mathrm{~m}$ thickness)

Core 144-878A-4R (28.5-38.0 mbsf, $0.7 \mathrm{~m}$ recovery): gastropod-bivalvepeloid mudstone to packstone, with oncolites or cyanobacterial nodules (Ortonella, "known as Cayeuxia in happier days" according to the core description)
25.6-30.0 mbsf: A high-resistivity bed is followed by an upward decrease to a medium-resistivity interval with a sharp upper contact to the next highresistivity unit. The lower bed has a "rubble" appearance in dynamic FMS imagery (Fig. 13). The FMS imagery within the upper beds suggests a lagoonal "wackestone-packstone" texture, and the recovered core pieces are considered to represent these lithologies.

Interpretation: A major storm bed is followed by a lagoonal environment.

Logging Facies Subunit IIA-5

(25.6-24.4 mbsf, top of FMS; 17 mbsf, base of drill pipe and top of resistivity $\mathrm{log}$; and $3.2 \mathrm{mbsf}$, top of platform facies according to core recovery); approximately $22 \mathrm{~m}$ thickness)

Core 144-878A-3R (19.0-28.5 mbsf, 0.7 m recovery): gastropod wackestone and packstone

Core 144-878A-2R (9.5-19.0 mbsf, $0.3 \mathrm{~m}$ recovery): peloid? gastropod packstone to wackestone with coarse shell fragments

Core 144-878A-IR (0.0-9.5 mbsf, 4.0 m recovery): gastropod wackestonepackstone; overlain by manganese nodule and phosphatized wackestone, and foraminifer nannofossil ooze

17.0-25.6 mbsf: This is a set of high-resistivity beds. The FMS imagery of the lowest bed (uppermost portion of processed FMS log) indicates a "rubble" texture with a sharp basal contact to the underlying low-resistivity facies.

3.0-17.0 mbsf: The geochemical logging record of calcium (Ca) provides a monitor of changes in porosity of the carbonate platform through the drill pipe (Fig.1). This calcium record was partially compensated for attenuation by the drill pipe by multiplying the values just above the drill pipe by a factor (approximately 1.5) sufficient to match to the calcium values just below the drill pipe; however, the main variations are apparent without the need for such scaling. The general character of the calcium record is similar to the underlying lime-mud-rich lagoonal facies interbedded with relatively less porous (higher resistivity and associated higher calcium values). The uppermost $2 \mathrm{~m}$ of the carbonate platform succession consists of a relatively well-cemented bed. Drilling rates also imply that the overlying succession is comprised of variable degrees of cementation capped by a hard-cemented uppermost bed (Shipboard Scientific Party, 1993). Uranium concentrations remain at low levels throughout this interval.

0-3.0 mbsf: A very porous interval (extremely low calcium) overlies the cemented top of the carbonate platform. This interval is pelagic chalk.

Interpretation: This interval displays possible cyclicity of variable stormredeposited debris. The combined evidence from the recovered facies, sustained low natural gamma-ray levels, and lack of a trend in the calcium log do not provide any indication of a late-stage upward-shallowing episode accompanied by algal-enrichment, as was characteristic of previous episodes of lagoon filling. The uppermost cemented bed of the carbonate platform probably resulted from submarine diagenesis, rather than a shallow-water sediment or storm-reworked accumulation, because the highest recovered facies of wackestone suggests quiet moderate-depth conditions. The final stages of the carbonate platform that can be observed in the downhole logs in Hole 878A appear to be a "lagoonal" facies with episodes of wave or current redeposition and winnowing. 